\title{
AN EXPERIMENT IN PREVENTIVE ANTI-TRUST: JUDICIAL REGULATION OF THE MOTION PICTURE EXHIBITION MARKET UNDER THE PARAMOUNT DECREES
}

\section{TABLE OF CONTENTS}

I. INTRODUCTION

II. The Amici Curiae: Quid Nomine? Quo Vadis?

III. Representative Cases: An Illusive Quest for Elusive CompetrTION.

The petition is granted without restriction.

Loew's Raritan Township petition

Loew's Greater Miami petitions

The petition is granted with some form of continuing judicial super. vision over the operation of the new theatre.

Stanley Warner's La Mirada petition

Loew's Jacksonville petition

The petition is granted, but the circuit's operation of other theatres in the same market is restricted.

Stanley Warner's Cheltenham petition

The petition is granted but the new theatre is subjected to product rostrictions.

Stanley Warner's Hamden petition

The petition is denied.

National General's Garden Grove petition

American Broadcasting-Paramount's :

Wilkes-Barre petition

Poughkeepsie petition

Fayetteville petition

IV. The Economics of the Acquisitions Cases : More Questrons ThaN ANswers.

A. Factors considered by the Court in Passing on Acquisition Petitions Under the Paramount Decrees.

B. An Economic Analysis of the Legal Criteria.

V. Preventive Anti-trust Gone Astrax: Judicial Prevention of Competrtion.

VI. Alternative Approaches to the AcQuisitions Clauses: A Return to Competition. 


\section{NOTES AND COMMENTS}

\section{AN EXPERIMENT IN PREVENTIVE ANTI-TRUST: JUDICIAL REGULATION OF THE MOTION PICTURE EXHIBITION MARKET UNDER THE PARAMOUNT DECREES}

\section{INTRODUCTION}

DURING the last decade an unnoticed series of skirmishes has taken place in the Southern District of New York between the nation's four largest motion picture exhibitors, their various local competitors, and the Department of Justice. This on-going conflict has been fought within the framework of judicial regulation of the motion picture exhibition industry under the acquisition clauses of the Paramount decrees. The wave of new theatre construction which has begun to sweep the country has provided the casus belli. Boasting extrawide screens, multidirectional sound and specially designed accoustics, no-draft air conditioning, ultra-modern appointments, and, above all, spacious parking facilities, the new theatres are decisive elements in luring patrons from their television sets and the vintage movies on the late show. This new wave of theatre building is one of the many effects of suburban expansion. Not only has a large segment of the theatre-going public moved to the suburbs, but so has the merchant whose customers have forsaken him in an effort to avoid the inconvenience of inadequate and costly downtown parking. The result has been the well-known growth of shopping centers in the new suburban areas and the increasing demand for entertainment facilities within easy reach of home. These external forces pulling the motion picture industry into suburban shopping centers have been matched by dynamic changes in industrial technology; theatres that cannot play Panavision, Todd-AO or Cinemascope films, along with their super-stereophonic sound tracks, are giving way to those that can.

The motion picture exhibitor's enthusiastic rush into new theatre construction is being led by the large national circuits. These national circuits are of two types: those which were themselves inspired by, and owe their current strength to, the present wave of modern theatre construction; and those which existed prior to World War II, and, at that time, completely dominated the national exhibition market. While all the circuits are similarly motivated, the older ones, formerly affiliated with the national production and distribution companies and now by virtue of the Paramount decrees separate entities, are building with a special energy. Their theatres, the "palaces" of a by-gone era, today the "dreadnoughts" in the industry, are typically located in the core of the city and are woefully outdated. Moreover, they are surrounded in most instances by decaying neighborhoods and frequently occupy properties which would bring a far higher return today if used for some other commercial purpose. In short, these older circuits in order to survive must follow their competition and patrons to the suburbs by purchasing or constructing modern theatres. 
Enter the Paramount decrees. These, the progeny of the famous antitrust case United States v. Paramount Pictures, Inc., ${ }^{1}$ stand athwart the efforts of the "older" circuits to acquire modern facilities. Stanley Warner, successor to the Warner Bros. theatre chain ; ${ }^{2}$ National-General, successor to the Twentieth Century-Fox chain $;^{3}$ American Broadcasting-Paramount Theatres, successor to Paramount Pictures ; ${ }^{4}$ and Loew's Theatres, successor to Loew's, ${ }^{5}$ owe their independent existence to the Paramount litigation in which eight major motion picture companies ${ }^{6}$ were convicted of violating the Sherman Antitrust Act. By judicial decree, these circuits ${ }^{7}$ were divorced from their parent companies and ordered to divest themselves of sufficient theatres to render the exhibition field competitive in all the major, and most of the minor, cities in the United States. ${ }^{8}$ These divestitures were designed to introduce competition to the many communities whose exhibition markets had been monopolized by one of the defendant circuits. It was thought that "opening" these "closed towns" would help destroy the base of the circuits' illegal market control, since the transfer

1. 334 U.S. 131 (1948).

2. At date of trial, Warner Bros. operated 501 theatres and controlled 20 others through joint ownership, with other defendants. Conant, ANTitrust in the Morion Picture Industry $49(1960)$. Hereinafter cited as Conant. This is the best available single volume of historical data on the industry before, and some years after, the Paramount case. Today Stanley Warner operates about 207 theatres. See note 224 infra for a general description of theatre ownership today.

3. National-General Corp. is the successor of National Theatres, Inc, the immediate successor of Fox. At date of trial Twentieth Century-Fox operated 636 theatres and controlled an additional 66 jointly with other defendants. Ibid. Todlay National-General controls approximately 225 theatres.

4. At trial date, Paramount operated 1,395 theatres and controlled 993 jointly. Today American Broadcasting-Paramount controls some 413 theatres. Ibid.

5. Operated 135 theatres independently, and 21 jointly with other defendants. Today Loew's operates about 56 theatres. Ibid.

6. Paramount, Loew's, RKO, Warner Brothers and Twentieth Century-Fox (known in the industry as the five majors), which were vertically integrated production-distributionexhibition firms; and Columbia, Universal and United Artists, the three minors, all of which engaged in distribution. The first two also were production companies.

7. The Radio-Keith-Orpheum (RKO) operated a circuit of 109 theatres independently of others and 187 jointly. It is not discussed in this Comment, and therefore reference is made to "four spin-off circuits" rather than five. The RKO Circuit has not been acquiring theatres, and presently has less than 54 theatres. See note 224 infra.

8. All the decrees were signed by a special statutory three-judge court, sitting in the Southern District of New York; they are cited:

United States v. Paramount Pictures, Inc. $1948-49$ Trade Cas. 62863 (S.D.N.Y. 1948) (the RKO Decree).

United States v. Paramount Pictures, Inc. 1948-49 Trade Cas. 63009 (S.D.N.Y. 1949) (the Paramount Decree).

United States v. Loew's, Inc., 1950-51 Trade Cas. 64544 (S.D.N.Y. 1951) (the

Twentieth Century-Fox Decree).

The Warner Bros. Decree, 1950-51 Trade Cas. 64264 (S.D.N.Y. 1951).

The Loew's Decree, 1952-53 Trade Cas. 67324 (S.D.N.Y. 1952).

These will be collectively referred to as the Paramount decrees. 
of market power from monopoly towns to competitive towns would thereby be prevented. In addition, the circuits were enjoined from maintaining any intercorporate relationship whatsoever with their former parents. ${ }^{\ominus}$ Finally, written into each decree, to the contents of which the newly created circuits were each required to consent, were provisions prohibiting them from acquiring

[A] beneficial interest in any theatre ... unless Warner's [or Loew's, or Paramount's, etc.] exhibitor successor shall show to the satisfaction of the Court, and the Court shall first find, that the acquisition will not unduly restrain competition. ${ }^{\mathbf{1 0}}$

These acquisitions clauses were the complementary enforcement mechanism to the divestiture clauses; in effect, the court was directed to prevent the reestablishment by the circuits of a monopoly position in any town. Thus, for Stanley Warner, National-General, American Broadcasting-Paramount and Loew's, the dash to the suburbs begins in the courtroom. Their adventures in the Southern District of New York, the court charged with supervision of the Paramount decrees, provide the subject matter of this Comment."

The Docket in Equity No. 87-273, United States 2. Paramount, shows several hundred entries since 1949 when the Southern District of New York undertook, by Supreme Court mandate, its continuing supervision over the bulk of the motion picture industry. ${ }^{12}$ As of January 31, 1963, roughly 65 of these entries represented petitions to the court pursuant to the acquisition clauses either to purchase existing theatres or to build new theatres. Approximately 40 million dollars of capital investment in leaseholds or fees were involved in these petitions, ${ }^{13}$ representing the purchase, construction, or long-term leasing of about 100 theatres. ${ }^{14}$

9. Decrees cited supra note 8.

10. The Warner Bros. Decree III, 6(b), supra note 8, at 64267 . Similar wording appears in each decree.

11. There have been several U.S. District Judges who have presided from time to time; but, since the late 1950's, Judge Edmund L. Palmieri has served as the judicial czar of the industry.

12. Most of the entries involved matters of administration, although a few were controversial and engendered substantial litigation. Only two complete lists of docket entries are available, one in the non-confidential files of the Department of Justice, and the other in the Southern District of New York. The Board of Editors of the Yale Lont Journal is grateful to Mr. Maurice Silverman, a senior trial attorney in the Department's Antitrust Division, for providing the author of this Comment with access to the Paramoum! docket and the extensive files which have grown up concerning it.

13. All acquisitions entries are under one of the following rubrics, United States $y$. Paramount Pictures, Inc.; v. Loew's, Inc; v. Warner Brothers, Inc.; v. Twentieth Century-Fox, Inc.; RKO has not been acquiring theatres. The original Equity case number, No. $87-273$ is used to identify every petition.

14. During the last two years, circuit petitions have been filed and adjudicated at roughly twice the pace of previous years, and, at date of publication, it may be estimated that their total now approaches 90 ; that the number of theatres is over 130; and that the capital investment involved, either planned or in being, is about \$58 million. These figures are, at best, only approximate, having been reached by averaging the known costs of roughly $\mathbf{3 0}$ acquisitions and multiplying the figure so derived against total acquisitions 
The theatres to be built all had a great deal in common. All were suburban facilities, constructed either in highly successful or very promising shopping centers or in the midst of the local business district of a suburban community. New drive-in facilities were customarily built on the fringes of the core city or of the suburban communities. Sometimes, although rarely, they were built in or near suburban business districts. In each instance, the areas concerned were undergoing population booms which made them among the fastest growing localities in the United States. Each theatre was equipped with the most up-to-date exhibition equipment, and, in the case of the conventionals or nondrive-in theatres, each was specially engineered with regard to accoustics, seating arrangements and climate control. The conventional theatres were, as a rule, of medium size, 900-1100 seats; the drive-ins varied markedly, ranging from 850 to 1350 in car capacities. Only in special cases was a proposed theatre significantly larger than the average size of the more important of its potential competitors. A broad generalization can be made concerning each of the new theatres proposed: on the face of the petitions and the affidavits filed in their support, each appeared to be an excellent investment in the economy of booming suburban communities; each would offer the movie-going public and the industry sorely needed modern facilities; and, lastly, each by its entry into the existing exhibition situation in its respective town, would significantly increase competition. In many instances, however, there were a group of vociferous local theatre owners, euphemistically labeled amici curiae, who were of a distinctly different persuasion, and in several significant cases, were able to obtain the sympathies of the Department of Justice.

The petitions to purchase pre-existing theatre facilities presented a different picture. Here the theatres were not necessarily new or well equipped, nor was the surrounding region necessarily growing in population and commerce. ${ }^{15}$ These theatres were chiefly drive-ins, ${ }^{10}$ acquired by the older circuits who had

minus a number of exceptional cases, such as the short-term leasing of Cinerama theatres. The $\$ 500,000$ per theatre figure so obtained may be somewhat high or low, but attorneys for the circuits have informed the author that it is as accurate as could be obtained considering the total absence of reliable statistics. Not included in any figures given above in text or footnote is the Stanley Warner Corporation's October 1962 acquisition, for roughly $\$ 6.5$ million of the Lone Star Circuit consisting of 37 pre-existing drive-in and conventional facilities. See United States v. Warner Bros. Pictures, Inc., 1962 Trade Cas. 77074 (S.D.N.Y. 1962). All acquisitions cases are heard solely in the Southern District of New York which has exclusive jurisdiction; all citations to papers filed and to records should be read as including (S.D.N.Y.).

15. Typical of these were the American Broadcasting-Paramount acquisitions in Wilkes-Barre, Pennsylvania and Fayetteville, North Carolina. See text accompanying footnotes 112-23, 137-45 infra.

16. In exceptional cases, however, pre-existing conventional theatres have been acquired. These have usually been part of a package including drive-ins, or can otherwise be explained by exceptional circumstances. An excellent example is provided by Stanley Warner's acquisition of the Lone Star Circuit in Texas. United States v. Warner Bros. Pictures, Inc., 1962 Trade Cas. 77074 (S.D.N.Y. 1962). The purpose of this acquisition was expansion and diversification into a new state and into the drive-in marlict. Lone Star Hearing Transcript, p. 9, Sept. 18, 1962." 
never been in the drive-in business prior to the Paramount decrees, in order to tap this rich and growing source of patronage. Some of the fiercest battles between the acquiring circuits and the amici curiae, as well as the largest number of failures to obtain court approval, were in this group of petitions. Here the Government seldom had to be won over by the amici; it was usually opposed at the outset, and rarely willing to compromise.

These two groups of petitions under the Paramount decrees - the petitions to build new facilities, and the petitions to buy pre-existing facilities - will provide the framework for an analysis of the District Court's administration of the acquisition clauses of the Paramount decrees. The relevant factors utilized in determining whether a proposed acquisition will "unduly restrain competition" will be examined; this standard will itself be evaluated; the results will be-assessed; and this unique attempt at preventive antitrust will be examined critically. Before launching on this journey, however, it will be essential to know something about who the amici curiae are, why they are so called, and what their role is in these proceedings.

\section{ThE Anici Curiae: Qum Nomine? Quo Vadis?}

The local competitors of the petitioning circuits did not gracefully accept so meek a status as amici curiae. For several years they struggled, in a few notable instances, for the right to intervene as full-fledged parties in interest. Arguing that the Justice Department would not properly represent the competing theatre owners' or the public's interest, these would-be intervenors cited the Government's refusal to undertake intensive studies of the "entire machinery used in exhibiting and distributing," in the competitive area affected by the proposed acquisition. ${ }^{17}$ Admittedly the Government never made such a survey. ${ }^{18}$ Pointing to the months that would be required for such detailed research, the Department of Justice customarily limited its inquiry to an evamination of the petition and its supporting affidavits, local maps, and conversations with interested parties. ${ }^{19}$ Another argument urged on the court was based upon the language of Rule 24(a) of the Federal Rules of Civil Procedure which reads:

Upon timely application anyone shall be permitted to intervene in an action:... (3) when the applicant is so situated as to be adversely affected

17. See the Wometco Television and Theatre Co.'s Mfotion for Leave to Intervene and Affidavit of Mitchell Wolfson, President, filed June 28, 1957. (Motion denied July 1; 1957, in the Loew's Miami Beach acquisition case.) See note 47 infro. The proceeding was a Loew's petition to acquire a conventional theatre in Mliami Beach, Florida, granted on July 10, 195\%. The language quoted appeared in the Wolfson Affidavit, p. 2. All papers cited are on file in the Antitrust Division's Paramount Docket.

18. The author's discussions with the senior trial attorney responsible for enforcement of the Paramount decrees, substantiated the amicus' point. The explanation is that such an investigation would be costly in time and manpower and is thought unnecessary by the Department. Moreover, the decree provisions on acquisitions are supervised by only one man, and it would be physically impossible for him to do more than rely on the affidavits of the parties, maps, and discussions and correspondence with competing theatre owners.

19. See note 18 supra. 
by a distribution or other disposition of property which is in the custody or subject to the control or disposition of the court. . . .20

It was also asserted that the acquisitions clauses of the Paramount decrees contemplated a full adversary hearing to inform the judge; else, how could he "first find," as the clauses require, "that the acquisition will not unduly restrain competition"? Only the would-be intervenor supposedly had the interest in bringing forth the requisite evidence of the petitioning circuit's illegal trade practices and proclivities to restrain competition. Finally, the local competitors customarily argued that leave to appear as amici curiae was an inadequate substitute for intervention, for only the intervenor had power to subpoena and adduce evidence, to examine and cross-examine witnesses, and to appeal.a1 Despite their superficial appeal, the arguments of the local competitors were roundly rejected. ${ }^{22}$

A major difficulty with allowing intervention in the proceedings under the acquisition clauses is inherent in the nature of the issues which the would-be intervenors wanted to litigate. Where the petitioning circuit had another thentre anywhere in the surrounding area, it was customarily charged that this theatre had obtained favored treatment from the distributor with which it was formerly affiliated and from the other distributor defendants in the Paramount case; that it was obtaining films without bidding, or despite bids lower than those its competitors made; and that it was obtaining a preferred run or better clearances ${ }^{23}$ than it deserved, all to the detriment of the complainant. The complainant wanted to intervene to prove these charges, using discovery proceedings, taking depositions, and trying all the issues of fact. Where the petitioning circuit had no such theatre in the immediate area, these allegations were still raised, albeit hypothetically, or in the guise of visiting the petitioner with the sins of its former parent, a defendant in Paramount.

Excellent illustration of the protracted litigation which such intervention would engender is provided by the proceedings surrounding the petition of the

20. FED. R. CTv. P. 24(a).

21. See, e.g., the argument made by the petitioning circuit's local competitors at the hearing on the Stanley Warner Corporation's Cheltenham acquisition, Oct. 14, 1960, Transcript pp. 12-13; see text accompanying notes 67-85 infra. See also the court's view of the amici's rights as non-litigants. Transcript pp. 54, 71.

22. See, e.g., United States v. Loew's, Inc., 136 F. Supp. 13 (S.D.N.Y. 1955); Cheltenham Transcript, supra note 21 , pp. 14-15.

23. A clearance is the period of time, usually stipulated in license contracts, which must elapse between runs of the same feature within a particular area or in specified theatres.

Runs are successive exhibitions of a feature in a given area, first-run being the first exhibition in that area, second-run being the next subsequent, and so on, and include successive exhibitions in different theatres, even though such theatres may be under common ownership or management.

United States v. Paramount Pictures, Inc., 334 U.S. 131, 144 n. 6 (1948). A preferred run is a first or a first neighborhood run, as the case may be, or simply an earlier run than a similarly situated competitor. A better clearance is merely a longer period of time. Clearances are usually measured in weeks; thus there are seven-day, 14-day, and 28-day clearances. 
Loew's Circuit to build a conventional theatre facility in Miami Beach, in June of 1957.24 The Wometco Television \& Theatre Co., the area's largest exhibitor (23 theatres in Greater Miami), ${ }^{26}$ sought to intervene, pressing all the arguments for intervention already mentioned. It had failed to convince the Justice Department in previous conferences, and consequently desired to try its case before the District Court. Loew's had only one other thentre in South Florida, the Riviera, constructed over the anguished protest of the Wometco Circuit two years before ${ }^{26}$ in a successful shopping center in Coral Gables, one of the fastest growing suburban towns in America. Prior to construction of the Riviera, no "neighborhood" theatre in Greater Miami had ever played first-run Miami; rather the distributors had permitted neighborhood theatres to exhibit feature films only after they had been shown for a given period in the downtown houses. The Riviera, however, from the time it opened, played nothing but first run. ${ }^{27}$ Disregarding the theatre's modern facilities, its spacious parking facilities and its ideal location across the street from the University of Miami, Wometco charged that the Riviera's great first-run success was the result of blatant discriminations and restraints of trade. It asserted that if Loew's were allowed to build a like facility in the northern portion of Miami Beach, approximately 24 miles away, it would similarly obtain discriminatory advantages and restrain competition. Wometco demanded leave to intervene, arguing that an intervenor's subpoena power was essential to obtain the evidence to prove

that it [Loew's] has used its "long purse" in bidding at the Riviera Theatre in the manner which the Supreme Court sought to avoid .... and also to prove that the Riviera is not one bit better either in performance or potential than several Greater Miami neighborhood theatres except that it bears the name Loew's, and that such theatres have not been allowed to obtain first-run pictures. ${ }^{28}$

Loew's, of course, denied everything, and charged Wometco with seeking only to delay the disposition of the application. The Loew's affidavits charged, moreover, not only that the Riviera had been required to bid competitively for product, having been shown no favoritism at any time, but that the Wometco chain

24. The only opinion in this case which was reported is that denying intervention, cited infra note 30 . All the data concerning the case has been extrapolated from the petitions and records of the procedings examined in the non-confidential files in the Paramoum case at the Department of Justice in Washington, D.C. The Loew's petition is dated June 11, 1957. The court granted it on July 10, 1957.

25. This figure comes from the papers filed in an earlier Loew's proceeding to acquire a conventional theatre in Coral Gables, Florida, dated Aug. 29, 1955 and also from the Loew's affidavit filed on July 11, 1957. Today, the Wometco circuit has roughly the same number of theatres in the Greater Miami area. Frus DAmY YEArsook of Aforios Pictures 1083 (1964). Wometco's closest competitors, Florida State Theatres, a subsidiary of American Broadcasting-Paramount, had 12, and Claughton Circuit had seven in the area.

26. This is the August, 1955, proceeding mentioned in the preceding note.

27. See Wometco's affidavit of June 28,1957, p. 3.

28. Id. pp. 6-7. 
has been favored because of its dominant position and buying power in the area. Wometco has on numerous occasions obtained product without bidding competitively, all to the detriment of the Riviera. . .

The issue was joined, and surely had the District Court permitted intervention, a private antitrust suit would have ensued with all the trimmings except the customary demands for treble damages.

The District Court refused to countenance such a prospect, ${ }^{30}$ in large part because of the ever-present danger that every acquisition petition under the decrees could easily turn into a private antitrust suit of unlimited dimensions. It had acted similarly in every prior case, and has done so since. In some of these cases ${ }^{31}$ the court has relied upon another argument which makes clear that no status other than that of amicus curiae can be available to the competing theatre owners. Without a clause in the final Paramount decree retaining jurisdiction over the original parties and the canse of action, the final decrees would close the record, ending the litigation and exhausting the court's jurisdiction. ${ }^{32}$ On the other hand, where the decree specifically provides for continuing jurisdiction, the court may grant additional relief, modify its prior orders, or entertain any action directly related to the original cause, as if the case were still open. ${ }^{33}$ This judicial power, however, is subject to one overriding qualification. As Judge Sugarman explained in denying a motion to intervene in an earlier Loew's acquisition proceeding, "when retained, ... . [continuing jurisdiction] will be exercised within the limitations of that retention." 34 Since the retained jurisdiction was limited in the decree to the original parties, ${ }^{35}$ the court is without power to subject Loew's, American Broadcast-

29. See Loew's Affidavit, dated July 11, 1957, p. 2.

30. The opinion is not reported. Wometco appealed to the Supreme Court from the District Court's denial of its motion to intervene. See Wometco Television \& Theatre Co. v. United States, 355 U.S. 40 (1957) affirming per curiam.

31. The court's views were previously set forth in other opinions, most notably in United States v. Loew's, Inc. 20 F.R.D. 423 (S.D.N.Y. 1957) and United States v. Locw's, Inc. 136 F. Supp. 13 (S.D.N.Y. 1955). Its attitude is also reflected in the cases most often cited by the court to support a denial of intervention, for example, United States v. A.S.C.A.P., 11 F.R.D. 511 (S.D.N.Y. 1951), and has been expressed from the bench. See, e.g., the Cheltenham Transcript, supra note 21, pp. 12-14.

32. United States v. Loew's, Inc. 136 F. Supp. 13, 14 (S.D.N.Y. 1955); Buckeye Coal \& Ry. Co. v. Hocking Valley Ry. Co. 269 U.S. 42, 47-48 (1925).

33. United States v. Loew's supra note 32.

34. Ibid.

35. The decrees all contained the following clause which seems to have been specifically designed to bar intervention by third parties:

Jurisdiction of this cause is retained for the purpose of enabling any of the parties and their successors to this consent judgment, and 120 others, to apply to the Court at any time for such orders or direction as may be necessary or appropriate for the construction, modification or carrying out of the same, for the enforcement of compliance therewith, and for the punishment of violations thereof, or for other or further relief. (Emphasis added).

The Warner Bros. Decree, XI(b), stpra note 8, at 64275. 
ing-Paramount, Stanley Warner, or National-General, the successors in interest to the Paramount defendants, to the subpoenas and examination of any third parties (here the competing theatre owners) every time the petitioning circuits seek court approval to build or buy a new theatre. Only the Government as the original plaintiff has such rights. To everyone else the Paranount case must be considered closed, and intervention therefore unavailable. ${ }^{30}$ Whether or not the Justice Department would properly represent the public interest is irrelevant. Should the petitioner's alleged behavior violate the antitrust laws to the detriment of the would-be intervenors, their remedy, if the Government refuses to prosecute, is an original private suit under the Sherman Act for treble damages. ${ }^{37}$

The issue of intervention in circuit acquisition proceedings was settled in the Loew's Miami Beach petition case; the court's denial of Wometco's motion to intervene was affirmed per curiam by a unanimous Supreme Court. ${ }^{29}$ The issue still arises on occasion, but the District Court now denies such motions from the bench. ${ }^{39}$ Neighboring theatre owners desirous of protesting a proposed acquisition are heard only at the sufferance of the court, and only then as amici curiae, with all the theoretical disabilities ${ }^{10}$ of that lesser status.

36. This rule has an ancient and honorable antecedent, United States v. Northern Sec. Co., 128 F. 808, 810 (C.C.S.D. Minn. 1904). The case being closed with the only exceptions being those provided for in the decrce, intervention by right under Rule 24a(3) of the Fed. R. Civ. P. must be foreclosed. The court never addressed itself specifically to the applicability of this rule; but it has dealt with the arguments for permissive intervention under Rule $24(\mathrm{~b})$. See note 31 supra and accompanying text. See also United States v. Loew's, 20 F.R.D. 423, 425 (S.D.N.Y. 1957).

37. See United States v. Bendix Home Appliances, 10 F.R.D. 73, 75-76 (S.D.N.Y. 1949). Adherence to the position taken in the text does not require the concession that competing theatre owners either could or would better represent the public interest. In the first place, their primary interest is in preventing the construction of a new competing theatre or the entry into their local market of a large national circuit by purchase of a pre-existing facility. Increased competition is just what they least desire. This is best illustrated by the saga of amicus Bailey, in Stanley Warner's Handen case, discussed at text accompanying notes 91-105 infra. And see note 203 infra. Moreover, the Supreme Court has rejected the proposition that the private businessman can protect the public interest in a public antitrust suit where the Government is present but does not choose to support the private individual's claim. See Buckeye Coal \& Ry. Co. v. Hocking Valley Ry. Co., 269 U.S. 42, 48-49 (1925). The court's primary concern is that the public's interest may be lost in the shuffe if private parties are allowed to intervene and threaten the Government's control of the proceedings. See United States v. Loew's, Ine 20 F.R.D. 423, 425 (S.D.N.Y. 1957). For reasons very similar to those given herein, intervention in the Paramount case itself was consistently denied. See Ball, Trustee v. United States, 333 U.S. 802 (1949) ; Partmar Corp. v. United States, 338 U.S. 804 (1949); United States v. Paramount Pictures, 334 U.S. 131, 177 (1948); Sutphen Estates, Inc, v. United States, 342 U.S. 19 (1951).

38. Wometco Television \& Theatre Co. v. United States, 355 U.S. 40 (1957) (per curiam).

39. See Cheltenham Transcript, supra note 21, pp. 14, 20.

40. See text accompanying notes 185-86 infra. 


\section{Representative Cases: An Illusive Quest for Elusive COMPETITION}

Since acquisition petitions filed pursuant to the Paramount decrees are heard in equity, ${ }^{41}$ the court has the power not only to grant or deny the petition, but also to grant it with conditions or restrictions attached. While the court has exercised its broad power in differing ways in numerous cases, the results can be descriptively classified under five major headings: (1) the petition is granted without restriction; (2) the petition is granted with some form of continuing judicial supervision over the operation of the new theatre; (3) the petition is granted, but the circuit's operation of other theatres in the same market is restricted; (4) the petition is granted, but the new theatre is subjected to product restrictions; and (5) the petition is denied.

\section{The petition is granted without restriction}

The Loew's Raritan Township petition ${ }^{42}$ was notable chiefly for the spirited contest waged against it by the amicus Keyport Theatre Company. Loew's sought permission to build a relatively small drive-in, in which it would own a one-half interest, on Route 35, ten miles south of Perth Amboy, New Jersey. Keyport Theatre Co. which operated a drive-in 3.5 miles from the proposed site, unsuccessfully sought to intervene, and then filed as amicus claiming that it would be adversely affected by the new theatre. Without the new theatre Keyport would have a near monopoly of the drive-in trade in the immediate area. The two closest competing drive-ins were 13.5 and 14.5 miles from the site of the proposed theatre. These were owned by Reade, a local circuit which dominated exhibition in this entire area of New Jersey and owned the only two first-run conventional houses in Perth Amboy, ten miles to the north; all six conventional houses in Asbury Park, 24 miles to the south; the one firstrun conventional house in Red Bank, 7.5 miles south; and others scattered in the smaller towns in the intervening areas. The Reade Circuit did not appear as an amicus or otherwise show any interest in the proceedings. The papers filed indicate considerable discussion over the relative distances between the amicus, the proposed theatre, and the other competing theatres in the Perth Amboy-Asbury Park-Red Bank area; the relative size of the competing theatres and the absolute size of the theatre-going population; and the present film distribution patterns in the area. The last received most emphasis.

On this point, Keyport argued that Loew's would be able to acquire for its drive-in theatre first-run product unavailable at that time to other drive-ins in

41. United States v. Paramount Pictures, Inc. 334 U.S. 131 (1948) was brought in equity under Sherman Act, 15 U.S.C. $\$ 4$ (1958), for injunctions and other equitable remedies.

42. The opinion allowing this acquisition is unreported; thus, all citations are to the papers filed with the court. The petition was filed November 15, 1955. Keyport Theatre Company's Motion to Intervene was made on November 23, 1955, and its supporting affidavits were filed on that date. All data given may be found in either of these two documents on file with the Department of Justice; separate citations will not be made. 
the area. Its proof, offered in affidavits, consisted of a showing that the other one-half interest in the proposed drive-in was in a son-in-law of the New Jersey distribution chief for Columbia Pictures, distributor of about 15 per cent of the total available product, and of an allegation that Loew's was a persistent antitrust violator and could be expected to use its considerable market power to coerce distributors to grant it a first-run position. After considering these arguments, as well as the factors mentioned above, the court permitted the acquisition with no restrictions. It relied heavily on the Government's refusal to oppose the application, and on the view that "The opportunity for antitrust violation standing by itself, does not constitute an adequate basis upon which to conclude such a violation." 43 Furthermore, the court said, it could always inquire into the fact situation which may later arise, should the new theatre indeed obtain first-run product when no other drive-in exhibitor was able to do so.

The result in this case is not atypical. In two other situations, for example, the Loew's circuit was permitted to acquire without restriction two theatres in the Greater Miami area, both times over the anguished cries of the local exhibition giant, the Wometco Circuit. The first, in 1955, involved the construction of the Riviera Theatre in Coral Gables. ${ }^{4}$ At that time, Loev's owned only one other theatre in the state, approximately 375 miles to the north in Jacksonville. Competition for product among exhibitors in the Greater Miami area was intense. The Wometco Circuit (23 theatres), the Florida State Circuit (12 theatres), and the Claughton Circuit ( 7 theatres), controlled all but two of the first-run houses in the entire area, a population center of roughly a million people. The distribution of product was on a competitive bidding basis, with downtown Miami, downtown Coral Gables, and downtown Miami Beach, playing the same first-run picture at the same time for the same period - called "day and dating" in the industry. In this situation, it is understandable that the court gave short shrift to Wometco's arguments that competition would be "unduly restrained" should Loew's be permitted to enter the market. In fact, with day and dating the modus vivendi, Loew's single house was at a distinct disadvantage, since Florida State, Wometco and Claughton had two or more houses for which to bid, all quite large and with prime locations. Industry practice across the country indicates that multiple first-runs, that is dayand-dating in various locations, are usually played in theatres owned by the same circuits. The explanation lies in the economies of group advertising. Local theatre owners, moreover, are reluctant to show films simultaneously with competitors, since it is easy for a competing house to take a free ride on advertising toward the cost of which it did not contribute; and the distributors gen-

43. On this point, the court cited Interborough News Co. v. Curtis Publishing $\mathrm{Co}_{\text {, }}$ 225 F.2d 289, 294 (2d Cir. 1955).

44. The opinion herein is unreported. Loew's Theatres \& Realty Co. filed its petition on Aug. 29, 1955 which was subsequently granted. All data have been derived from the papers filed, and from interviews with local theatre operators who requested that their names be withheld. 
erally respect this reluctance. 45 This situation apparently prevailed in Greater Miami, and the result was that because Loew's Riviera was usually forced to play first-run by itself, it lost much high quality product which the distributors preferred to open on multiple first-run in commonly owned theatres. ${ }^{40}$

Two years later, Loew's filed its petition $\mathbf{~} \mathbf{7 7}$ to build another conventional facility 24 miles northeast of the Riviera Theatre, at the other pole of the Greater Miami exhibition market. The site was ideal in every way. Like the Riviera site, it was located in a flourishing shopping center with abundant parking facilities and in the midst of an area experiencing booming commercial and population growth. The immediate locale was greatly under-served by theatre facilities. The closest competition was a medium size drive-in, 3.3 miles away, operated by Wometco. The only other significant competitors were 8-10 miles south in central Miami Beach and 7-8 miles north in central Fort Lauderdale. Since arguing that competition would be unduly restrained was at least as farfetched in this instance as it was in the Riviera petition, Wometco, appearing as amicus curiae, ${ }^{48}$ contended instead that Loew's was guilty of anti-competitive practices. It asserted that the Riviera's first-run position was the result of collusion between Loew's and the distributors, and that the latter had brolsen their long-standing policy of requiring all Greater Miami first-run exhibition to be confined to the downtown areas of Miami, Miami Beach, and Coral Gables, thus discriminating against all other exhibitors in favor of Loew's. Wometco argued that the distributors' action was unjustified because 'the Riviera is not one bit better either in performance or potential than several Greater Miami neighborhood houses. . . .40 While the alleged distribution pattern existed in fact, there was no evidence in the record that it was the result

45. Such considerations have begun to undermine the theatre-by-theatre buying and selling injunctions of the Paramount decrees. Although bids are offered and received for individual houses, it becomes obvious from a casual reading of local theatre listings in New York City, for example, that multiple runs are played mostly on a circtit or chain basis. This has consistently been true in Miami where Wometco's Carib, Miami, and Miracle Theatres always play day-and-date. Regardless of the way in which bidding or negotiating is in fact accomplished the effect is clear; in areas where multiple runs are common, a single-theatre operator is at a real disadvantage.

46. There were numerous exceptional instances; the Loew's Riviera day-and-dated occasionally with one of Florida State's theatres or with one or more of the Claughton Circuit's houses, sometimes, too, with one of the very few independent houses in the area. There is no evidence that Loew's Riviera ever played day-and-date with any of Wometco's theatres. This additional information was obtained from August, 1964 intervicws with theatre operators in the Miami area, who have requested to remain anonymous.

47. Loew's Theatres and Realty Co., filed its petition in the Southern District in June, 1957. Wometco's papers seeking intervention were filed on June 28, 1957. The intervention was denied on July 1, 1957, and the petition was granted on July 10, 1957. The opinion and order are unreported. All data has been derived from these papers, on file with the Department of Justice, and from interviews with theatre operators in Miami, who have requested that their names be withheld.

48. See discussion of Wometco's attempt to intervene, in text accompanying notes 25-30, supra.

49. See notes $27 \& 28$, supra. 
of a deliberate, unjustified discrimination against the dominant Wometco, Florida State and Claughton chains, merely to benefit Loew's single theatre. Indeed, for a distributor to discriminate against South Florida's largest exhibitors in favor of its smallest would appear to be irrational. Thus, once again over Wometco's protests, Loew's acquisition petition was granted without restriction. ${ }^{51}$

The petition is granted with some form of continuting judicial supervision oucr the operation of the new theatre

The Stanley Warner Corporation's La Mirada, California, petition ${ }^{\text {t2 }}$ is the most prominent in this category. Stanley Warner sought to build a new conventional theatre in a shopping center in the town of $\mathrm{La}$ Mirada, a suburb of Los Angeles. Population growth had been phenomenal, soaring from 5,000 in 1920 to 22,500 in 1960 , when the town was incorporated. This growth was not atypical; 380,000 people lived within a five mile radius of the site, a 200 per cent increase in ten years. La Mirada had no conventional theatre and only one drive-in, about 2.5 miles from the proposed site. Fourteen drive-ins and 34 conventional houses, a total of 48 competitors were located within a 13 mile radius.

There were several active and vociferous amici in this case, who convinced the Department of Justice and the court that there were too many theatres already servicing the area, and that the new theatre could, and very well might, drive some of the existing theatres out of business, especially if economic expansion and population growth in the area tapered off. Accordingly the court's decree retained sufficient supervision to prevent such a "grave possibility":

This grave possibility impels me to pause. The resolution of the problem depends, in the last analysis, upon the course of future population and business trends in the area. . It is likely that most of the theatres will continue to operate and it is likely that this rapidly developing area will continue to grow. But I prefer to defer a definitive decision because of the unusual facts here presented. I have accordingly inserted the following provision in the order I am filing herewith:

"ORDERED, ADJUDGED AND DECREED that the petitioner, $\ldots$... may acquire the New Theatre, provided that within sixty (60) days after the first fifteen (15) months of operation it submits to this

50. In fact, the evidence seems to have been very much to the contrary. See text following note 27 , supra.

51. Today, the Loew's Riviera and 170th Street Theatres, as the most recent theatre is called, play day-and-date on almost every occasion, drawing their patrons from within a 12-mile radius of each theatre. They are highly successful, and, in the opinion of several observers, their presence had made a considerable contribution to a genuine competitive atmosphere in the Greater Miami exhibition market.

52. United States v. Warner Bros. Pictures, Inc., 1961 Trade Cas. 78480 (S.D.N.Y. 1961) (hereinafter cited as $\mathrm{La}$ Mirada). The petition was filed in late July, 1961, and the hearing was held on Aug. 16, 1961. The data in the text came from the petition, from the supporting and contesting papers filed in the Southern District of New York, and from the hearing transcript. All papers are on file in the Antitrust Division in the Paramount Docket. 
court appropriate proof that the operation of said theatre on a firstrun basis has not constituted an undue restraint of trade. Such proof shall include a sworn statement of the nature and extent of moving picture exhibition conducted within a 13 mile radius of the proposed site, at the end of said fifteen (15) month period."

*** Its right to continue its proposed theatre on a first-run basis will abide the submission of the proof required by the order filed herewith. ${ }^{08}$

A careful examination of the transcript of the hearing and all supporting papers filed does indeed turn up "unusual facts"; but, they are facts which make it a great deal less than pellucid how this new theatre could possibly "unduly restrain competition." Of the 48 theatres serving this area, 35 played multiple first-run. Of the remaining 13 theatres, six played Mexican, nudist, or strictly foreign product, and seven played permanently on subsequent run. Since the La Mirada would be a first-run theatre, and since first and subsequent run houses are not traditionally considered in the same market, ${ }^{\text {th }}$ the 35 first-run houses alone should have been the proper objects of concern. None of the 35 were by any means weak sisters. Nine multi-theatre companies owned all $35: 55$ the National Theatres Circuit with 250 theatres, operated six; the Pacific Drive-in Corp., then a 43-theatre chain, operated 14; amicus Stein, then a 28-theatre operation, owned three; amicus Electro Vision Corp., then a 14-theatre chain, operated one; Sterling Theatres Co., a 32-theatre chain, owned one $;^{56}$ amicus Vinnicof, then operating seven, owned four; amicus Bruin operated three; and amicus Cummings, a five-theatre concern, operated two. Stanley Warner, the petitioner, already owned one. Since there was no pattern of exclusive first runs, with any one theatre obtaining a clearance over all of its competitors, it was probable that Stanley Warner's La Mirada would be compelled to play day-and-date with other theatres on a multiple first run. In this posture, it was unlikely that the new theatre would deprive existing theatres of much product. ${ }^{57}$ In addition, given the large number of threatres in the area, any loss of patrons probably would be spread over many box offices.

53. Id. at 74481. (Emphasis added).

54. But see complete discussion infra note 166 .

55. Included in this figure are drive-ins playing multiple first and second runs, the consensus being that for a great part of the year in this market, drive-ins and conventionals were directly competitive.

56. This theatre, the La Mirada Drive-in, was listed in the papers filed by the parties in the name of one M. A. Appleman; but the Sterling Company, a Seattle-based operation, is in fact the owner. See Fils Daily Yearbook of Motion Pictures 1076 (1964).

57. The explanation for this statement is that each theatre playing on a multiple run, that is, playing the same film day-and-date with other houses, is by definition located in such a geographic position that it is only minimally competitive for the same patrons as the other theatres with which it plays day-and-date. If this were not truc, there would be no reason to play the same film at more than one theatre. Hence, each multiple first-run zone is a local sub-market unto itself, and it is presumed that competition to show product in that geographic sub-market will only be between theatres located in it. At the time that Stanley Warner filed its petition, the town of La Mirada, the probable multiple first-run submarket, had no conventional theatre and only a small 
The five amici united in protest and filed joint affidavits repeating the same arguments. These were of two related kinds. The first was too many theatres and too little product:

By any rule of thumb, whether it be population vs. theatres, or population vs. number of theatre seats, the La Mirada area is supersaturated with theatres and has an over-abundance of theatre seats. This means that the theatres in the La Mirada area are competing with each other on a very vigorous basis. This is particularly true because of the shortage of film product, which is a situation well known to all in the industry. ... [T] he La Habra Theatre, for the past several years, ... has just barely remained in the black. The profit we earned was nominal and in no way justifies the very substantial investment which we have in the theatre. If Stanley Warner builds the La Mirada Theatre, which is only $21 / 2$ miles from La Habra, it will only make our economic plight more precarious. ${ }^{.8}$

Second, Stanley Warner will have an overwhelming advantage in obtaining the little product available:

The fact that Warner Brothers [sic: Stanley Warner] at the moment operate only six theatres in the state of California is not important, but the fact that [it] still operates approximately 250 theatres on a national basis, almost all of these theatres being theatres of size and stature located in principal cities, is important. The fact that they do maintain principal offices in New York City where the heads of the film distributing companies are located, and the fact that they maintain highly paid large staffs in New York City and are able to use their vast buying power and bring to bear pressure and influence, also is important and places the independent exhibitor, who has none of these advantages in a secondary and most unfavorable competitive position. ${ }^{69}$

With regard to the validity of these arguments, it must suffice at this point merely to say that the first directly conflicts with the purpose of the acquisitions clauses of the Paramount decrees - to foster a fiercely competitive exhibition market throughout the United States; and the second would simply penalize bigness and geographical location of main offices without any evidence of illegality in either and without any rational connection to the promotion of competition. Nevertheless, both points had peculiar effectiveness in the La Mirada case, as the opinion excerpted above indicates.

The result of the case is especially difficult to justify in light of the "unusual facts here presented," to use the court's phrase, which destroyed the amici's position. Amicus Vinnicof had just completed construction of a new theatre in the same area five months before; amicus Stein had, at about the time of the La Mirada hearing, announced plans to construct a new facility also in the same area, and amicus Electro Vision had just then announced plans to build

drive-in 2.5 miles away. Thus, the new theatre, if it played on multiple run, was unlikely to deprive any theatres of very much product since its competition to obtain the multiplerun was so limited. Certainly it would not very seriously affect all or most of the existing 35 theatres within the 13-mile radius fixed by the court.

58. Karp affidavit on behalf of Electro Vision Corporation (amicus curize), p. 2, dated Aug. 31, 1961, Ia Mirada.

59. Stein affidavit, (amicus curiae), p. 2, dated Aug. 30, 1961, id. 
a $\$ 750,000$ theatre, not only in the same competitive area, but also within 2.5 miles of its own existing La Habra Theatre which it was lamenting that Stanley Warner's La Mirada would ruin. ${ }^{60}$ Moreover, a make-believe atmosphere fell over the whole proceeding when it was proved by Stanley Warner that the General Drive-in Corp., one of the nation's most successful "independent"01 chains, was prepared and in fact had agreed with the owners of the La Mirada Shopping Center to pick up Stanley Warner's option to build, without further negotiations, should the court deny Stanley Warner permission to construct the theatre. ${ }^{62}$ Despite the fact that these events had been called to its attention, the court, supported by the Department of Justice, feared for the health of competition in exhibition in the La Mirada area and found it necessary to provide for continuing judicial supervision. Although the order was scruptulously followed, the report filed by Stanley Warner pursuant to it ${ }^{63}$ leaves no doubt of the futility of the whole exercise. Since the La Mirada Theatre opened, the area continued to grow, adding 300,000 additional persons. The amici curiac in total disregard of their fears about too many theatres and too little product, continued to build and add theatres to their circuits. Moreover, no theatre existing when the La Mirada opened had gone out of business.

Another form of continuing supervision, taking a somewhat more prophylactic approach to antitrust law enforcement, is the "thou shalt not" decree with penalty attached if "thou shalt." There are several decrees of this type presently outstanding. The Loew's petition to purchase the Normandy Drive-in ${ }^{\circ}$ is characteristic. In this instance, Loew's was permitted to buy from a single independent exhibitor a 1350 car-capacity drive-in in Jacksonville, Florida. The theatre was on subsequent run, 21 days after first run Jacksonville. Since all of Jacksonville's 18 conventional and 11 drive-in theatres were considered within the relevant market, the area looked substantially competitive. Despite this situation, the court, without articulating its reasons, allowed the purchase, but with restrictions providing the existing competitors with a protective and supervisory decree:

60. The data as to the construction activity of the amici curiae is given in the Schwartz \& Frohlich letter to the court, dated Sept. 23, 1961, pp. 3-4, and in the affidavit of Simon Fabian, President of Stanley Warner Corp., dated Sept. 18, 1961, pp. 3 and 3n 1, 15, 19 and Exhibits B and B-1, id.

61. The descriptive adjective "independent" is frequently used by the court and the parties to denote any theatre operator not formerly affiliated with a Paramount defendant. It is a misleading appellation. See note 77, infra.

62. Affidavit of Simon Fabian, President of Stanley Warner Corp., supra note 54 and Exhibit $C$, $i d$, and copies of correspondence between General Drive-in (now General Cinema Corp.) and the shopping center management attached thereto.

63. Affidavit of Harry M. Kalmine, Vice President and General Manager of Stanley Warner Corp., dated April 20,1964, and filed on that date in the Southern District of New York, and in the Antitrust Division of the Department of Justice.

64. Loew's petition was dated May 20, 1955, and was granted on June 2, 1955. No report of the opinion and order is available; the records of the Antitrust Division of the Department of Justice were used and all data comes therefrom. 
If, during a period of three years from the date of the acquisition of the Normandy ... by petitioner, an independent operator in substantial competition with the Normandy . . . is not afforded a reasonable opportunity to procure films for such theatre on the availability afforded the Normandy ... if he so desires, then the Normandy Outdoor Theatre, if it continues operation on a run of 21 days after 1st run or earlier (but other than first run) shall be subjected to a product limitation as hereinafter set forth. $0^{05}$

Added to the decree was the provision that if the court should decide, or the parties agree, that the condition stated above has occurred, then for the succeeding three years the Normandy shall not license more than 60 per cent of the feature films released by the eight major distributors. ${ }^{\circ 0}$ There is no available evidence to indicate whether this clause has ever been invoked.

The petition is granted, but the circuit's operation of other theatres in the same market is restricted

The Stanley Warner Corporation's Cheltenham petition ${ }^{07}$ was the occasion for a pitched battle between the dominant exhibitor interests in the Cheltenham area of Philadelphia and a petitioning circuit which had been suffering a continuous decline in its ability to compete for top quality product in the Philadelphia market. The theatre to be constructed by Stanley Warner was to cost roughly $\$ 500,000$ and to have 1200 seats and the most modern facilities and design currently available. Population had increased considerably in this outlying district of Philadelphia, and the site was in an immense, ideally located and highly successful shopping center with an estimated draw of approximately 1 million customers from metropolitan Philadelphia. The amici curiae were the operators of the two closest theatres: the Ellis Circuit - the second largest chain (21 theatres) in the Philadelphia area ${ }^{88}$ — operating the Erlen, at that time the sole theatre on key, or first-neighborhood, run; and Mr. Melvin Koff, owner of the Keswick Theatre. The key run in this clearance zone had an availability of 21-28 days after downtown Philadelphia. The petitioner, Stanley Warner, also operated in the Cheltenham area the Yorktown Theatre (820 seats) and the Lane Theatre, a strictly art and foreign product house.

For some time, the Cheltenham section of Philadelphia had been noncompetitive. The Erlen (Ellis) and the Yorktown (Stanley Wamer) had split all available product along distributor lines, each playing exclusively the product

65. Order, dated June 2, 1955, id.

66. This $60 \%$ of major product limitation is the arbitrary percentage limitation chosen by the 3-judge court, which wrote the Paramount decrees, for purposes of giving "independent theatres a crack at quality product." See the Warner Bros. Decree, sspra note $8, V(1)$ n. 4.

67. The petition was dated Sept 26, 1960; the Ellis Circuit's motion for leave to intervene and supporting papers were dated October 8,1960; and the court's opinion and order were dated November 22 and 23, 1960, respectively. The opinion alone is reported, United States v. Warner Bros., 1960 Trade Cas. 77397 (S.D.N.Y. 1960) (hereinafter cited as Cheltenham).

68. Affidavit of Frank J. Damis, Vice President and Philadelphia Zone Mranzger, Stanley Warner Corp., dated Nov. 2, 1960, p. 10. 
of one or more distributors. ${ }^{60}$ The Keswick (Koff), slightly further north, in Glenside, played the product of all the distributors, without bidding against the Erlen or the Yorktown, often playing day-and-date with either. At some point, probably at about the time the Ellis Circuit renovated the Erlen, a bidding situation developed due to Ellis' refusal to continue the split ${ }^{70}$ with the Yorktown. The two houses, no more than 1.8 miles apart, could not profitably play day-and-date with each other. The Erlen, with 1600 seats was about twice as large as, and better appointed than, the Yorktown. According to the testimony of Stanley Warner's zone manager,

We [Stanley Warner] got our brains knocked out. We bid against the Erlen with 800 seats against 1600 . Even though our Yorktown ... is . . . very nice, the Erlen ... is a real beautiful theatre with lots of seats, and we couldn't compete.

Q. He was outbidding you, is that correct?

A. Sometimes we bid ... and it would cost us 90 per cent of the gross, and $I$ think in one instance it cost 100 per cent of the gross. . . . We couldn't afford to take these losses, so we ... . decided not to bid any more. ${ }^{71}$

Thereafter, the Erlen and the Keswick were the sole key run houses in the area. Stanley Warner fell back to subsequent neighborhood run, behind the Erlen. ${ }^{72}$

Since Cheltenham Township was a highly promising market and the new shopping center an ideal site, Stanley Warner saw an opportunity to re-cnter the key run competition by constructing a new facility. At all times, Stanley Warner made clear its intention to compete with the Erlen, as well as with the Keswick, and on cross examination at the hearing Stanley Warner's zone manager testified that he anticipated a bidding situation would develop against both the Erlen and the Keswick. ${ }^{73}$ Since the new theatre with its immense parking facilities (space for 4400 cars), ${ }^{74}$ was expected to draw on the patronage of the full half-million people living within a five mile radius of the shopping center, and since Stanley Warner intended to request exclusive key run on the product for which it would bid, with clearance over both Erlen and Keswick, all three theatres would be in "substantial competition" for the same patronage. ${ }^{75}$

As would be expected, the catalog of arguments advanced by the amici Ellis and Koff, illustrated the entire gamut of contentions put forward from the first

69. Cheltenham hearing Transcript, pp. 70-72, Oct. 14, 1960.

70. "Split," when used as a noun, is a term of art referring to a division of film product either along distributor lines as in the Cheltenham area or as explained infra, notes 236-242 and accompanying text. No judgment will be made at any point in this Comment on the legality of this form of market division under the antitrust laws. For its incidence in the national exhibition market, see note 133 infra.

71. Cheltenham hearing Transcript, p. 74.

72. Id. p. 75 .

73. Id. pp. 87, 90, 95-96, 97.

74. Stanley Warner's Memorandum on the Facts, dated Nov. 4, 1960, p. 8.

75. See note 73 supra. 
acquisition petition to date. Present, with varying degrees of evidentiary support, were the following: overall population may be increasing, but thentregoing population has fallen off; there was a severe shortage of quality boxoffice product, especially of the type appealing to this kind of neighborhood; this particular key run clearance zone had sufficient theatres to fill the demand, the emergence of the Erlen as the sole key run theatre in Cheltenham demonstrating the zone's inability to support more than one such theatre; for these reasons no economic justification for the new theatre existed, and therefore Stanley Warner's purpose in building the new theatre must be to drive Messrs. Ellis and Koff out of business by using its superior resources to procure the bulk of the better product ${ }^{76}$ The most serious difficulty with the last argument, and thus a fortiori with the three points preceding it, was that Smith Management now the General Cinema Corp., one of the nation's leading and most dynamic "independent circuits," "77 was at the time of the hearing negotiating with the Cheltenham Shopping Center management to erect a theatre on the same site should Stanley Wamer's present plans go astray. ${ }^{78}$ Surely this fact was better evidence of the genuine need and the commercial justification for a new theatre than the victory of the Erlen over the puny Yorktown was to the contrary. For General Cinema would hardly be willing to sink $\$ 500,000$ in an unprofitable theatre in the impossible hope of obtaining a monopoly by driving the Erlen out of business and by simultaneously preventing entry by other competitors, even were it initially to be conceded that Stanley Warner would be so foolish. Apparently, however, the fact that the amici fortified their arguments with loud and repetitious assertions of the probability of anticompetitive practices was sufficient to convince the Court that the amici's arguments vere credible despite their evident dubiety.

Seeing which way the wind was blowing, Stanley Warner fought hard, taking issue with each point, and emphasizing in particular that the new theatre would create two key run houses in the Erlen's clearance zone, and would thus conform to the general pattern in the Philadelphia area. The fact was that the majority of key run zones of similar composition contained two or more key run theatres; ${ }^{79}$ clearly the Erlen had no vested right in a key run free from

76. Mr. Eilis' language, on p. 10 of his affidavit, is quoted in the reply affidavit of Frank J. Damis, Vice President and Zone Manager for Stanley Warner, supra note 68, pp. 2,9.

77. Though commonly called "independents," circuits like General Cinema are no more independent than Stanley Warner or Loew's; the appellation is misleading. It originated in pre-Paramount days when there were only two types of theatres, those affiliated with the defendant producer-distributor-exhibitors, and those which were not. Today, the appellation "independent" continues to arise in case after case, see, c.g., note 61 supra, and accompanying text, although it is now meaningless. As the District Court itself has said: "These theatre companies [the spin-off circuits] are no less "independent circuits' ... than the many substantial companies not subject to the decree with whom petitioner is in competition all over the country." Lone Star Circuit opinion, 77077. The appellation "independent" should be quietly interred.

78. Stanley Warner's Memorandum on the Facts, p. 9.

79. Damis Affidavit, id. p. 13. 
any substantial competition. The decisive factor in the court's decision in favor of the construction, however, was the Government's lengthy memorandum finding substantial business justification for the investment, and arguing what was later to be repudiated in the La Mirada case - that "a circuit has every right to compete for whatever patronage there is in an area whether it be declining, rising, or static. .. ." 80 On the other hand, the Department of Justice agreed with the amici that there was indeed "a shortage of quality . . . and significant box office pictures," a situation which justified restrictions on Stanley Warner's' ability to compete overall in the Cheltenham area. ${ }^{81}$ In brief, the restrictions which were suggested and later written into its decree by the court, were designed to insure that Stanley Warner would be unable to operate "any more key run theatres in the area than any one of its present competitors. . .", and to this end the decree permanently enjoined the petitioner from operating its Yorktown or Lane Theatres on key run as long as the Ellis Circuit operated only one key run house in the Cheltenham area..$^{83}$

80. Memorandum on Motions to Intervene and on the Memoranda and Affidavits of Amici Curiae, filed by the Department of Justice, Antitrust Division, p. 4 Nov. 6, 1960.

81. Id. p. 7; see the discussion concerning this alleged product shortage, and criticism thereof, as a justification for competitive restrictions, notes 208-14 infra, and accompanying text.

82. Id. p. 10.

83. Ibid. The text of the Cheltenham Order follows. It will be referred to frequently in subsequent sections of this Comment, and may profitably be compared with the Hamden Order, see text at note 101 infra.

ORDERED, ADJUDGED AND DECREED that the Petitioner, Stansery WARNER CoRPoration may acquire the New Theatre, and it is further ordered:

- 1. That so long as Petitioner operates the New Theatre on a first neighborhood run policy, Petitioner shall not exhibit on first neighborhood run at its Yorlstown Theatre ... and/or its Lane Theatre. ... any feature picture [exclusive of foreign language pictures and British films] distributed by the defendant distributors in Equity Case Number 87-273, except as to

(a) any such feature picture for which competitors who have had an opportunity to request licenses on first neighborhood run have not made an offer or have made an insubstantial offer, but nothing contained in this subparagraph shall be deemed to authorize the playing of any such feature picture at the Yorktown Theatre on first neighborhood run day and date with both the New Theatre and a competitor of the Yorktown Theatre, or

(b) any such feature picture exhibited at a competitive theatre on first neighborhood run with respect to which the operator of such or any other comcompetitive first neighborhood run theatre has not requested clearance or priority of run over the Yorktown Theatre or the Lane Theatre, which such picture may be played at the theatre over which clearance or priority of run has not been requested; or

(c) any such feature picture exhibited at the Renel Theatre [owned by the amicus Ellis Circuit] on first neighborhood run, when the operator of the Renel Theatre is also operating the Erlen Theatre on a policy of playing such pictures on first neighborhood run, which such pictures may be played at the Yorktown ... or Lane, ... but not both.

2. The provisions of paragraph 1 shall cease to apply in the event that the operator of the Renel Theatre in Philadelphia,... [the Ellis Circuit] shall opcrato 
On the whole, the Cheltenizam order is not unusual and has parallels in other situations. Most commonly, however, the restrictions are slightly less extreme, and the acquiring circuit is enjoined only from playing day-and-date, new theatre with old, from "averaging off" bids between its houses, or from playing its own move-overs ${ }^{84}$ in its older houses, unless its competitors had a chance to bid for the subsequent run.85

Another important aspect of the acquisitions clauses was unvittingly revealed by the Government's memorandum to the court in the Cheltenham case. The conclusion of the memorandum demonstrated the Department of Justice's failure to appreciate that its suggested order would restrict the ability of the petitioner to operate according to the policies dictated by its independent business judgment. The Department stated:

The Government does not believe the issue to be how many theatres or how many key tun theatres this competitive area needs or should have. This is a business judgment to be made by Stanley Warner ${ }^{80}$ just as it would be made by any exhibitor not subject to a judgment who proposed to enter into this area with a new theatre which it was proposed to operate on the key run. ${ }^{87}$

This statement is impossible to reconcile with the Government's proposal, later adopted by the court, which prevented Stanley Warner from operating another theatre on key run regardless of the number of such houses which business in the area warranted. Even worse, Stanley Warner's business judgment was made dependent upon that of its leading competitor, for the order stipulated that the petitioner could only move another theatre up to key run if the amicus Ellis had done so first. ${ }^{88}$ Whether or not the Cheltenham order had a beneficial effect on competition, the Government was taking part in a process by which it and the court were performing a function directly analogous to that performed by a regulatory commission issuing a conditioned certificate of public

the Renel ... . on a policy of playing pictures released by the defendant distributors on first neighborhood run, when such operator is also operating the Erlen Theatre on such policy; but in no event shall Petitioner at any one time operate more than two of the New Theatre, the Yorktown Theatre and the Lane Theatre on first neighborhood run.

Cheltenham Order, dated Nov. 22, 1960, filed Nov. 23, 1960, in the Southern District of New York (unreported). It was also provided that if the petitioner should operate the New Theatre on a first run Philadelphia basis, the Yorktown may not be similiarly operated. Ibid.

84. A move-over from first or any other run is a continuation of that run of a picture in a second theatre.

85. See, e.g., United States v. Loew's, Inc, 1962 Trade Cas. 76373, 76376. (S.D.N.Y. 1962) (San Jose, Calif.) (hereinafter cited as San Jose); and see the provisions of the Hamden Order, note 101 infra, and accompanying text.

86. Loew's, National-General or American Broadcasting-Paramount may be freely substituted, and the reader could place this paragraph in any one of a dozen Government memoranda or hearing transcripts in an equal number of acquisition cases.

87. Memorandum, supra note 80 , at 11 .

88. Cheltenham Order, subpara. 1(c), and para. 2, supra note 83. 
convenience and necessity. Nor is Cheltenham atypical. To date, the acquisitions clauses of the Paramount decrees have been read as invitations for the Government and the court to substitute their judgment for that of the market place as to how many theatres should be operating. ${ }^{80}$ Indeed, their performance in many cases is reminiscent of that of the $C A B$ which has often limited entry into certain markets in the airlines industry in order to preserve the market positions and investment of existing carriers..$^{00}$

The petition is granted but the new theatre is subjected to product rcstrictions

In this category Stanley Warner's Hamden, Connecticut, petition ${ }^{21}$ is the paradigm case of the logical extreme. Stanley Warner sought to acquire a conventional shopping center theatre in suburban Hamden, on the fringe of the New Haven metropolitan area. There were 13 existing conventional theatres in this metropolitan area, four of which played first run on a permanent basis, and there were also four drive-ins on stubsequent run. The first-run market was only minimally competitive. The three downtown New Haven houses, Loew's College, Stanley Warner's Roger Sherman, and American Broadcasting-Paramount Theatres' Paramount, "split" or allocated the first run product of the major distributors among themselves without bidding competitively for it. ${ }^{92}$ The Whalley Theatre, a semi-neighborhood house, owned by the amicus Mr. Bailey, a local multi-theatre operator, successfully bid from time to time against whichever downtown house would otherwise have obtained the partictlar picture. ${ }^{93}$ Most of the time, however, the Whalley negotiated directly for product without bidding, and usually played extended-run road show attractions. Amicus Bailey owned the most theatres in the New Haven area, ${ }^{04}$ operating in addition to the Whalley two neighborhood theatres of somewhat ancient vintage, both playing first-run day-and-date with each other, usually with less than top quality product. He also had interests in the sole New Haven art and foreign product theatre, the Lincoln, a very small and poorly appointed establishment. In addition, Bailey owned the fee of the Crown, the only downtown theatre specializing in unusual films, typically of good quality, on their last and final runs. The entire New Haven area was treated by all parties as the appropriate competitive market, and although there was some discussion of the dis-

89. See, e.g., The La Mirada case, where the court was concerned that there were too many theatres in the competitive area, discussed in text supra at notes 52-53.

90. See, e.g., Southern Service to the West Case, 12 C.A.B. 518 (1951), in which the C.A.B. denied additional entry into transcontinental routes across the sotthern United States because such entry would divert business from and decrease the reventues of existing carriers. Id. at 524-32, passim.

91. United States v. Warner Bros. Pictures, Inc., 1961 Trade Cas. 78290. Order filed June 28, 1961 (order unreported) (hereinafter cited as Hamden). All the data given in the text comes from various papers filed and the hearing transcript.

92. See discussion of the "split," supra, note 70, and infra notes 236-42.

93. Hamden hearing Transcript, June 1, 1961, p. 13.

94. The data on Bailey's holdings and interests comes from the Stanley Warner Petition, pp. 6-7, filed in the Southern District of New York on March 20, 1961. 
tances between the competing houses and the proposed new theatre, it was apparent from the outset that all theatres were considered within one large first-run clearance zone. The resulting disturbance of the existing distribution pattern by the entry of new competition was a possibility which neither the amicus, the Department of Justice, nor the court was willing to permit.

At the urging of the amicus Bailey, the Government took the position that the acquisition should only be permitted if Mr. Bailey's Whalley Theatre could be protected. The Whalley was a 942 seat house about 1.4 miles from the downtown theatre district. It was more than 20 years old and had been renovated from time to time, but was unable to show the newest-technique wide screen films. ${ }^{95}$ As compared to the proposed new theatre in terms of its ability to serve the movie-going public and the distributors who hoped to maximize their return on each film released, the Whalley was decidedly at a vell-merited disadvantage. The new theatre was to have 1150 seats and to be located in the midst of a very large shopping center with parking facilities for over 1500 cars. It would be the first theatre constructed in Greater New Haven since World War II, and thus be the only one to possess the requisite equipment to exhibit "every presently known one-strip process, including 70mm, Todd AO, Panavision, Cinemascope" as well as the standard $35 \mathrm{~mm}$ pictures. ${ }^{90}$ The theatre also would be far more attractive than the Whalley and much better appointed. It was to be designed with every modern theatre development: no-draft air-conditioning, specially engineered accoustics, and special speakers to provide "super stereophonic sound never heard before in [the] area." In every way it would be an ideal first-run house, well suited to road-show use, and especially well qualified to exhibit the most recent developments in modern motion picture entertainment. As such, it would be a strong competitive force, and a threat to the market position of all existing theatres in Greater New Haven. The Whalley, however, was considered by the Government and the court to be the key to the public interest in the "preservation of competition"; and, at the cost of rendering the new theatre unable to exhibit the first-run product for which it was designed, the Whalley was to be preserved. The Government's argument cannot be paraphrased without losing its flavor:

Stanley Warner does presently operate one of the four theatres in New Haven which are first run ... playing primarily the first-run releases of the seven major distributors .... . If the new theatre becomes a first run theatre of this kind, it means that it will be superimposed upon a first run position that Stanley Warner already has in the New Haven area. Because of the way product is offered for licensing in New Haven . . . if conventional first run product is siphoned away by the new theatre from any of the competing first run theatres, it is likely to be the Whalley from which it is siphoned. If this should eliminate the Whalley as a first run

95. Ibid. The Whalley's inability to show all the latest wide screen product accounts for the restrictive provision in subparagraph (b) of the Hamden Order, text at note 101 infra.

96. Id. pp. 5-6.

97. Ibid. 
theatre, it, of course, would mean the elimination of a competitor and give Stanley Warner two of the four first run theatres in the New Haven area instead of one of the four as at present. The net result would be an enhancement of Stanley Warner's first run position and a corresponding diminution of its first run competition. Any such result, in the view of the Government would mean that competition will have been unduly restrained. Accordingly, the Government has suggested restrictions on the operation of the new theatre, calculated to assure that the impact of the new theatre will not be to deprive the Whalley of the first-run product of the seven major distributors. . . .88

Even if it is assumed for the sake of argument that the public interest in competition can be, or is, safeguarded by preserving competitors, the above rationale is not very convincing. In the first place, if the new theatre were to siphon product away from anyone, it would probably be first from the existing members of the split, and then from the Whalley. Initially, the members of the split, Stanley Warner, American Broadcasting-Paramount, and Loew's could be expected to rearrange the existing market division, and this could only be done by each one giving up some product which it formerly would have obtained to the new theatre. In the past the Whalley had been highly successful in bidding "across the split" and taking pictures away from the Paramount, the Loew's College and the Roger Sherman ;09 since the split would presumably continue with the new theatre's participation, the Whalley would not be forced to bid head-on against the new theatre for every film it wanted. ${ }^{100}$ And in bidding against the other theatres in town, no reason was advanced why it should automatically be less successful after the construction of the new theatre by Stanley Warner. In any event, some evidence should have been required as to whether, should the many competitive advantages of the new theatre truly be overwhelming, the amount of product the Whalley would lose would indeed put it out of the first-run market, or simply render it somewhat less profitable. Whereas concern for the continued existence of the Whalley may be relevant to those who see the antitrust law as a means of protecting existing entrepreneurs from extinction by more efficient and attractive competitors, concern for insuring existing levels of profit is entirely unfounded for it makes the antitrust law a means of providing a guaranteed annual income for businessmen.

Such bothersome questions never arose, however, and the competitive restrictions written into the decree effectively rendered the new theatre a subsequent run house by severely restricting its access to first-run product. The resulting order represents the logical extreme of a decade of effort to trans" form the acquisitions clauses of the Paramount decrees into instruments for insulating existing local theatre owners from the forces of change sweeping the industry. The major operative clause of the Hamden order read as follows :

98. Memorandum on the Position of the Government, Department of Justice, p. 3, dated June 12, 1961.

99. Note 93 supra.

100. This is because the whole concept of the split would require that the new theatre remove itself from the market for many films. 
1. So long as Petitioner operates the Roger Sherman Theatre in New Haven, Connecticut, on a first run policy, Petitioner shall not exhibit at the New Theatre on first run feature motion pictures released by the major distributors of motion pictures except as follows:

(a) During any three month period commencing January 1, April 1, July 1 and October 1 of any year feature motion pictures released by the major distributors may be shown on first run at the New Theatre for a period of time corresponding to the aggregate period of time feature motion pictures, released by the major distributors, have been shown on first run at the Whalley, Westville, and Whitney Theatres during the preceding three calendar months, less fifteen weeks.

(b) There may be shown, in addition to the pictures which may be shown pursuant to the preceding subparagraph, such pictures released by the major distributors on first run for which independent competitors who have had an opportunity to request licenses on first run have not made an offer or have made an insubstantial offer. Independent competitors shall not be deemed to have had an opportunity to request licenses within the meaning of this subparagraph when a major distributor offers a picture, which will be released in $35 \mathrm{~mm}$ and $70 \mathrm{~mm}$ or other wide screen process, for licensing for its first run New Haven showing only in $70 \mathrm{~mm}$ or such other wide screen process. ${ }^{101}$

Subparagraph (a) is complex and requires some explanation. In brief, the Whalley would require 13 weeks of first-run product per quarter to operate continually as a first-run house. The order guaranteed Mr. Bailey that Stanley Warner's new theatre would not be able to operate on first-run unless he obtained sufficient product for 15 weeks of first-run for all three of his theatres. Obviously, he could use no more than 13 at the Whalley, and therefore had two extra weeks of first-run for the Whitney and the Westville Theatres before he would be faced with any first-run competition from the new theatre. In practice, the order was completely unworkable. ${ }^{102}$ Stanley Warner could do no planning at all until the number of weeks Bailey played first run were known, and these were always subject to change until the last moment, depending upon the profitability of the particular movies booked in that quarter. Thus each given three month period had to end before Stanley Warner could know how many first run films it could bid on for the next three months. However, once the previous three months had expired, the product for the next quarter of the year had already been booked by the distributors into other first-run houses including Bailey's. As Stanley Warner's losses began to mount and it prepared to return to court for modification of the order, Bailey relented and agreed to

101. The Hamden Order, dated June 27, 1961, filed June 28th, pp. 2-3. There were other clauses of the decree which prevented the new theatre from playing move-over runs from, or playing day-and-date with, Stanley Warner's other first-run house, the Roger Sherman, unless in the previous three months amicus Bailey's three theatres had played move-overs or day-and-date; and, then, such move-overs (defined in note 84 supra) and day-and-dating were permissible only for an equivalent time.

102. Telephone Interview with Mr. Stuart H. Aarons of the Office of the General Attorney, Stanley Warner Corp., on Feb. 5, 1965. 
enter a major product split covering all Greater New Haven's first run houses. The New Haven first-run market is now totally non-competitive with the existing market division frozen, and effectively maintained by the court's decree. Both Bailey and Stanley Warner have every incentive to make the current split work: the former gets better product than he might otherwise obtain in a bidding situation $;^{103}$ and the latter is released from a severely restricted position into which it may again be thrust if the split should break down.

Subparagraph (b) is self explanatory, although its effects prior to the recent split require brief elaboration. The new theatre, being the only one capable of showing $70 \mathrm{~mm}$ film, would have been able, without the restriction in subparagraph (a), to obtain all wide-screen films offered by the distributors to the New Haven market. Subparagraph (b), while permitting the new theatre to show $70 \mathrm{~mm}$ films where no substantial bid had been made for the film by one of its competitors, severely limited this concession by requiring that all films offered to the New Haven market be made available in both 70 and $35 \mathrm{~mm} .^{104}$ With top quality product, it was unlikely that the first-run New Haven moviegoer would ever see $70 \mathrm{~mm}$ or other wide screen processes for his money unless the requirements of subparagraph (a) were met permitting Stanley Warner to bid for such product. As a consequence, the New Haven moviegoer, by virttue of the decree, would likely have been deprived of the most exciting visual achievements of recent motion picture technology. ${ }^{105}$

103. This aspect of the New Haven "split" is unusual; ordinarily no competitor gets better product - rather, he gets the same product more cheaply. See text accompanying notes $239-40$ infra.

104. Subparagraph (b) of the order, text at note 101, supra, does not, of course, require in ipsissimis verbis that the distributors offer all film in $70 \mathrm{~mm}$ and $35 \mathrm{~mm}$ in Greater New Haven. However, subparagraph (b) excludes wide-screen film product, which is not also offered in $35 \mathrm{~mm}$, from those films which the new theatre can show free of the restrictions in subparagraph (a).

If a film is offered only in $70 \mathrm{~mm}$, and if the conditions in subparagraph (a) allowing the new theatre to play first run have not occurred, then the new theatre cannot play that $70 \mathrm{~mm}$ film; consequently, that film will not be shown in New Haven, no theatre other than the new one being equipped to show it. For this reason, the distributors, prior to the recent split between the Whalley and the new theatre, were, in effect requircd to offer all product in $35 \mathrm{~mm}$ as well as $70 \mathrm{~mm}$, as if the new theatre did not exist.

105. In certain instances, this is still the case today; but, in general, because of the Greater New Haven product split, to which Bailey finally agreed, Stanley Warner's new theatre gets a good deal of wide-screen product. A recent example is the contest which developed over the "Sound of Music," which was released by Twentieth Century-Fox in both $70 \mathrm{~mm}$ and $35 \mathrm{~mm}$. Since the Whalley was tied up for a long "road show" of "My Fair Lady," Bailey bid for the Whitney Theatre, a much older, 895 seat house capable of showing $35 \mathrm{~mm}$ alone. He made a "substantial offer" and invoked the Hamden Order, subparagraph (b), and Fox was prepared to adhere to it. Had Bailey not been moved by Stanley Warner's pleas that he adhere to the agreed split, which would have given the film to Stanley Warner's new theatre, the public would have been forced to see the "Sound of Music" on its first-run in $35 \mathrm{~mm}$, a much narrower screen than $70 \mathrm{~mm}$, and to hear its musical score over less modern musical facilities than those available in the new theatre. Interview with attorneys for Stanley Warner Corp., April 9, 1965, New York City. 


\section{The petition is denied}

One of the first cases to fall within this category was National Theatres' (the spin-off circuit of Twentieth Century-Fox) Garden Grove, California petition. ${ }^{106}$ Garden Grove, in Orange County about 25 miles from Los Angeles and about one mile from Disneyland, was the fastest growing community in the United States in 1957, the year of the petition. At the time of the petition, Garden Grove had only one theatre, a thirty-year old house about 1.75 miles from the proposed site with a seating capacity of 410 . The Vinnicof Circuit, the most vociferous of the protesting amici, was at that very moment building a 1000 seat conventional theatre in the town. Despite the phenomenal growth of the area, only three theatres had been constructed in the entire county since 1945, the new Vinnicof theatre and two older houses, one 8.5 and the 4.6 miles from Garden Grove. Twenty theatres, including the new Vinnicof theatre and seven drive-ins, were within a ten-mile radius with an estimated population of 506,374 . Of the 20 theatres, National operated four, the closest of which was 2.5 miles from the proposed site. With the exception of the three theatres built since World War II, all the existing conventional houses were out-moded and deficient in parking facilities. Three of National's four houses in Orange County were among the worst in both of these respects, being 36,35 and 30 years old respectively and all unable to exhibit the latest wide-screen pictures. The fourth National theatre was 12 years old, but had been built before the new exhibition technology had come into use. As a result, these theatres were becoming less able to wage effective competition, and National was having increasing difficulty obtaining quality product. Three of its theatres were already on subsequent run while the fate of the fourth was in doubt. Moreover, the great potentialities of the area made it likely that the Vinnicof chain would not be alone in seizing such excellent exhibition opportunities by building modern capacity. Others, such as Pacific Drive-in or General Drive-in, for example, could be expected to follow suit, and their entry would probably have elimininated National's last first-run foothold. These were the reasons underlying National's desire to construct an ultra-modern 1000 seat conventional theatre with parking facilities for 500 cars. These were also the reasons why National argued that it could not possibly "unduly restrain competition" by its proposed construction.

The Government, while it was not opposed, still did "not feel that it could recommend National's petition."107 The amici, not surprisingly, were very much opposed. They argued that the new theatre would give National enough

106. Petition dated June 11, 1957; court's opinion and order of July 26, 1957, is unreported. However, the opinion said only that petitioner had not sustained its burden of proof that competition would not be unduly restrained. All the data and arguments which follow in the text have been extracted from the petition and affidavits as filed by the parties. These papers are collected in the Antitrust Division of the Department of Justice in its copy of the Paramount Docket.

107. This was the statement of the Government's trial attorney at the hearing. It is quoted in National's Brief in Support of Motion for Reargument, Aug. 7, 1957, pp. 5-6. 
leverage to dominate the first-run market, placing them at a competitive disadvantage; that quality product was already too short to service adequately all existing first-run houses in the area; and that National had engaged in anticompetitive practices such as pooling its purchasing power and bidding from its "long pocketbook."

As to the possibility that it would dominate the first run market, National replied that something more than a bare assertion was necessary, since, with the new acquisition, it would have one of four first run theatres within a fivemile radius, hardly a preponderance by any calculation. This argument should have been especially convincing, since day-and-dating on multiple first runs was very common in this area. ${ }^{108}$ Moreover, National urged the court to consider the fact that the local competitors were all strong and well-managed and that drive-in competition against conventional houses was especially fierce in Orange County. As National pointed out, three large modern drive-ins capable of serving 10,000 persons were operated within a ten-mile radius of the site by one of the strongest competitive chains in the West, Pacific Drive-in Corp.; and the amici's assertions to the contrary notwithstanding, these drive-ins catered in large part to the same clientele. ${ }^{100}$ As a final, broader-gauge rebuttal of the amici's charge of dominant position, National pointed to the strong first-run competition in the entire Los Angeles market offered by the Pacific Drive-in Corp. Its large demand for product to fuel its 35 other drive-ins and three conventional houses in the Greater Los Angeles metropolitan area allegedly gave it a favored position with distributors which National could never hope to surmount fully. As to its alleged anticompetitive practices, National relied heavily on the Paramount decrees' requirement that distributors license films theatre-by-theatre and film-by-film, thus maling circuit buying and other antitrust violations based on the pooling of purchasing power unlikely. Such an argument had been successfully made in other similar cases, in some in-

108. This means that no one theatre had exclusive first-run, with clearance over all the rest. Moreover, the presence of multiple runs, with their concomitant day-and-dating between houses, indicates the existence of several sub-markets rather than one major geographic market. See note 57 supra. Thus the number of theatres a circuit possessed would give a misleading picture of market share since all the thentres are not in the same submarket. See note 57 supra; and accompanying text. For the validity of the technique of isolating submarkets, see Brown Shoe Co. v. United States, 370 U.S. 294, 336 (1962). In any event, as this Comment demonstrates in a subsequent section, see text following note 174 infra, the entire technique of measuring market share by aggregating a circuit's theatres in a geographic market and finding the percentage which this total bears to all theatres in that market, is unreliable and erroneous.

109. The question of how competitive the drive-ins were in the Los Angeles area was close; and from the appearance of the record no one would seem to have obtaincd the upper hand. The competitiveness of drive-ins is difficult to assess, since local climate, daily weather conditions, and many other intangibles are inextricably interwoven. But industry consensus seems to be that, in climates where seasons change (unlike Los Angeles and Miami), the drive-in is a formidable competitor in summer time. 
stances by the court itself, ${ }^{110}$ and it is reasonable to assume that it received judicial acceptance in this case.

Nevertheless, one or more of the amici's contentions were apparently suffcient to carry the day, since the Garden Grove case closed with National suffering the most notable defeat on record with regard to petitions to construct new theatre facilities. Regrettably, the court was content to render an opinion devoid of explanation; the above arguments, which have been culled from the affidavits and briefs of the parties, provide the only clues to what transpired.111

In the category of petitions to buy pre-existing facilities, American Broadcasting-Paramount Theatres has the dubious distinction of having suffered the most surprising losses. The latest of these was its Midway Drive-in petition 112 in Jenkins Township, just outside the limits of Wilkes-Barre, Pennsylvania. Midway, an independently owned theatre, was one of 22 theatres, and the smallest of 11 drive-ins in the Wilkes-Barre area. American BroadcastingParamount already owned two conventional houses, one the leading first-run theatre, and now wanted to enter the drive-in market. Petitioner's "foremost competitor,"113 the Comerford Circuit, with five theatres, was the largest exhibitor in the area. The other 15 local theatres were "independently"114 owned. The Government opposed the petition, and three competing theatre owners appeared as amici curiae, in protest.

The court mentioned five factors which it considered of importance to its decision that the petitioner had not "sustained its burden of showing that competition will not be unduly restrained."115 First, the economy of WilkesBarre, based on coal-mining and railroad installations, was "in the throes of an economic slump of some duration. As a consequence, all the theatre owners

110. An excellent example of the Court's impatience with arguments from the Government or amici curiae which presume that the circuits will abuse their purchasing power and violate the antitrust laws in found in the Lone Star Circuit acquisition opinion, United States v. Warner Bros. Pictures, Inc, 1962 Trade Cas. 77074 (S.D.N.Y. 1962), which, while five years subsequent to Garderi Grove, merely restates a view which the court had expressed from the bench in many prior proceedings.

111. On Aug. 7, 1957, National Theatres filed a motion for re-argument which gives its assessment of the court's result:

9. Undue weight appears to have been attached to objectants' fears that the construction of a theatre by petitioner in Garden Grove would put them at a competitive disadvantage.

10. Undue weight appears to have been attached to the desires of the new Vinnicof theatre to be protected from competition.

Brief for Reargument, pp. 4-5. The reargument was denied.

112. United States v. Paramount Pictures, Inc. 1962 Trade Cas. 77101 (S.D.N.Y. 1962) (hereinafter referred to as Wilkes-Barre).

113. This is the court's appelation. Ibid. Comerford today operates 42 theatres in two states, Pennsylvania and New York. Finur DaIIY Yeareoos of Motron Pictures 1047 (1964).

114. This adverb is the court's, but it is difficult to say what the court meant. See notes 61 \& 77 supra.

115. Wilkes-Barre Opinion. 
have been experiencing operating difficulties."110 Second, with the addition of the Midway Drive-in, petitioner's seating capacity would rise to 16.68 per cent of the total in the area,

a greater percentage than that held by American-Paramount when the [Paramount] Consent Judgment was entered, although the market has substantially declined since the date of that judgment. ${ }^{117}$

Third, combined seating capacity, ${ }^{118}$ petitioner's plus the Comerford Circuit's, would be 50.3 per cent after the purchase. Fourth, "another independent competitor of these two chains is eliminated."110 Fifth, the purchase of this drive-in would enable petitioner to dominate the drive-in market in the Wilkes-Barre area:

[P] etitioner, through the Midway acquisition would place itself in a position to outbid other drive-ins for first-run pictures, thereby protecting its theatre in downtown Wilkes-Barre from drive-in competition. ${ }^{120}$

Although all of these arguments contain flaws, the fifth and last deserves immediate attention because its unquestioned acceptance is so well illustrated in the context of this case. Its use as one of the bases of decision prestipposes that the court accepted the validity of several highly questionable premises. First, to conclude that American Broadcasting-Paramount's ownership of the Midway Drive-in would enable that drive-in to outbid all its drive-in competitors for quality product, the court must have assumed that all American Broadcasting-Paramount's competitors, due to some peculiar disadvantage each possessed vis-a-vis American Broadcasting-Paramount and no one else, would be unable to offer the distributors similar inducements to obtain first-run product, with regard to either or both the desirability and attractiveness of their facilities and the dollar amounts of their bids. ${ }^{121}$ Second, in order to conclude that the purchased drive-in, assuming arguendo that it could obtain a monopoly of quality first-run product, would enable the petitioner to protect its downtown conventional house from drive-in competition, the court must have assumed that such protection was within the realm of economic feasibility. This last assumption is untenable. In obtaining its first-run monopoly by out-bidding all drive-in competitors for best quality product, the petitioner could not avoid adversely affecting its downtown house, thereby incurring a double cost. Then, to protect its downtown house, petitioner would have to shift its drive-in to subsequent run or to low quality product, in order to permit its downtown house to play first-run without drive-in competition. Simultaneously, the peti-

116. Ibid.

117. Ibid.

118. Ibid. This combined capacity figure is a very unusual aspect of the Wilkes-Barre case and has no analogue in any other acquisition case.

119. Ibid.

120. Ibid.

121. This is an assumption which is particularly untenable since the Midway Drive-in was the smallest and far from the nicest in the area. Moreover, it was so located that there was no room for expansion. Interview with Haliburton Fales, II, Est., Attorncy for American Broadcasting-Paramount Theatres in the Wilkes-Barre case, April 9, 1965. 
tioner would somehow have to prevent the other 10 drive-ins from re-entering the first-run film market. None but the most irrational businessman would ever set out on so futile an endeavor. ${ }^{122}$ Another interpretation of the court's fifth argument is possible, but it, too, demands irrational conduct on the part of the petitioner. The court might have thought that the drive-in, after achieving its monopoly of first-run product, would retain it, and play day-and-date with the petitioner's downtown theatre. However, since the "protection" argument proceeds from the premise that all the drive-ins and the downtown houses are competitive for the same patrons (in the warmer seasons), were the petitioner to day-and-date its drive-in and downtown theatres, it would merely create competition with itself. Petitioner would thus be no better off in terms of "protecting" its downtown conventional theatre than if the drive-in had remained in a competitor's hands. ${ }^{123}$ In any event, the principles from which the court's premises are derived and the data on which they presumably rest, are nowhere stated in any judicial opinion or economic study in this field.

A consideration of two petitions simultaneously filed and denied by the court, roughly a year before the Wilkes-Barre case, further illustrates the peculiar characteristics of petitions dealing with pre-existing theatres. The two cases involved the purchase of two theatres, one in Poughkeepsie, New York, and one in Fayetteville, North Carolina. ${ }^{124}$ In the Poughkeepsie case the Government, joined by an amicus curiae, was firmly opposed to the acquisition. The court's

122. The only time when it is conceivable that a drive-in facility can protect a downtown conventional theatre is found in those situations where the drive-in in question is the only drive-in in the relevant competitive area. In such a case, the circuit plays subsequent-run or low quality first-run product exclusively in its drive-in, thus malsing a smaller profit at the drive-in but protecting its conventional house - and all others in the area, for that matter - from meaningful drive-in competition. In Wilkes-Barre there were 11 drive-ins, and it is impossible to see how such protective action, or any other, would work.

123. The only rebuttal to this reasoning is the argument that the drive-in and conventional downtown theatres do not play to the same patrons, and thus woud not be in competition. But if such were the case, the drive-in could not, in any event, either "protect" or competitively injure the conventional downtown house.

If it is asked why the petitioner could not adequately "protect" his downtown theatre by merely insisting on an exclusive first-run, with adequate clearance for every film it licenses, the answer is that this approach, too, would likely fail. In the first place, it is common practice of most distributors in popular drive-in areas to offer product during the summer only for day-and-date showing, drive-ins with downtown conventionals. In such a case, a downtown operator cannot demand and pay for an cxclusive run, since he is not given an opportunity. Secondly, in many areas where the distributor does not demand day-and-dating by conventionals with drive-ins, the latter operators usually offer to play day-and-date, and the resulting profits available to the distributors could not be equalled by any single conventional exhibitor bidding for an exclusive run, no matter how much he might offer.

124. United States v. Paramount Pictures, Inc, 1961 Trade Cas. 78724 (S.D.N.Y. 1961). Both petitions were denied in the same opinion, but after separate discussions, which will hereafter be referred to as the Poughkeepsie opinion or the Fayetteville I opinion, respectively. 
opinion set forth reasons for denial similar to those advanced in Gardcn Grovc and Wilkes-Barre: that the acquisition would "constitute a significant rise in petitioner's seating capacity in the competitive area," thus giving American Broadcasting-Paramount a "more dominant position"; 125 that petitioner would have "a position of even greater dominance from the standpoint of first-run capacity"; 126 and that a potential independent competitor, who had just completed building the theatre sought to be purchased, would be eliminated.

None of these arguments, however, were decisive. The case appears to have gone off on the point that petitioner had engaged in anticompetitive practices. ${ }^{127}$ The court put it this way:

The petition is presented against a factual background which indicates that the exhibition of first-run pictures in this area has not been characterized by vigorous competition. 128

Since the leading exhibitors in the area were obtaining product generally in accord with an agreed split, the court was undoubtedly correct in this regard. ${ }^{129}$ Nevertheless, for two related reasons, this finding cannot be taken literally as the ratio decidendi. First, acquisition petitions have been approved in situations where split of product existed.130 Second, were such a finding to result in each instance where competitive bidding had been eliminated by a "splitting" device, it would seem to follow that such market divisions are to be treated as presumptively illegal - a conclusion which the courts have contint1ally refused to draw. ${ }^{131}$ The "factual background" of the case, however, was unusual, and for this reason may provide insight into the court's otherwise unarticulated rationale for decision.

Prior to the Paramount decree, Poughkeepsie was a closed town on firstrun; petitioner's predecessor, Paramount Pictures, Inc., operated all three firstrun houses. The decree required petitioner, upon its creation, to divest itself of one of them; and not long after doing so, or perhaps at the same time, American Broadcasting-Paramount and its divestee agreed to split product and thus effectively to eliminate competitive bidding. The Government maintained, in fact, that the agreement also eliminated all competition and thus rendered the

125. The Poughkeepsie opinion 78724.

126. Ibid.

127. Interview with Mr. Maurice Silverman, Attorney, Department of Justice, Antitrust Division, June 15, 1964, Washington, D.C.

128. The Poughkeepsie opinion 76725.

129. If, however, the Court meant to say that the "split" was evidence of the existence of non-competitive theatres, this implication would be erroneous. See text accompanying notes 236-42, infra.

130. The Cheltenham and Hamden cases, discussed in text accompanying notes 67 \& 91, supra, are examples, as is United States v. Loew's, Inc, 1962 Trade Cas. 76373, 76374-376 (S.D.N.Y. 1962).

131. See, e.g., United States v. Loew's, Inc, supra note 130, and the list of cases cited by the court therein at 76374. See also, Viking Theatre Corp. v. Paramount Film Distrib. Corp., 320 F.2d 285, 292-93 (3d Cir. 1963), aff'd by an equally divided Court, 378 U.S. 123 (1964), rehearing detied, 85 S.Ct. 15 (1964). 
divestiture itself futile, since petitioner virtually retained its monopoly position in the market. The protesting amicus even went so far as to assert that American Broadcasting-Paramount still controlled all three first-run theatres. In the Government's papers there were also intimations that some kind of tie existed between petitioner and its divestee rendering the latter something less than a free operator. It was this alleged state of affairs which renders the case somewhat unusual. ${ }^{132}$

The petitioner met these arguments with the contention that the split was merely a voluntary agreement giving no guaranteed access to film product to either party. Each competitor negotiated alone with the distributors for the product on its side of the split. The distributors had complete freedom with respect to their choice of exhibitor for a given picture; they could refuse to license the party to whom that picture may have been assigned on the split, and instead license the other if the former party did not live up to the distributor's competitive expectations. The distributor, moreover, could demand competitive bids for any particular picture. ${ }^{133}$ Although these arguments were apparently considered unsatisfactory by the court, it is difficult to be certain which of the opposing arguments raised by the Justice Department and the amicus was preferred; the court's opinion contains nothing but the cryptic sentence on competition excerpted above. The amicus' argument - which reduced to the position that American Broadcasting-Paramount's "long purse" made competitive bidding unacceptable regardless of whether petitioner bought the existing drive-in - was least likely to have carried the day, since it was clearly inconsistent with the Government's position attacking the split. The Government, on the other hand, never met petitioner's arguments, nor overcame the effect of petitioner's point that the Government had approved and supported splits in other situations. ${ }^{134}$ Instead, the Government shifted emphasis and insisted that in this particular case the split was illegal because the distributors had never consented to it and the market division was in effect little more than a hori-

132. American Broadcasting-Paramount contested this point fiercely, putting on witnesses who testified to the contrary and offering much evidence to support its position. It is not at all clear from the record who had the best of the argument.

133. The product arrangement and modus vivendi with the distributors described in the text is very common. See, e.g., cases cited supra note 131. In fact, there is evidence that genuine competitive bidding for product occurs in only a small proportion of the total selling situations in the country - somewhere around 32\%. See Cassady, Impoct of the Parannount Decision on Motion Picture Distribution and Price Making, 31 So. Car. L. REv. 150, 161 n. 77 (1958). Whether or not the figure was then accurate, or is today, seven years later, most industry attorneys interviewed insist that it is the exception rather than the rule to find competitive bidding in any given situation.

134. See Testimony of Assistant Attorney General Barnes, Hearings Before Subcommittee of the Senate Select Committee on Small Business, 83d Cong., 1st Sess. at 651-52 (1953) ; and Letter from Assistant Attorney General Lee Loevinger to Edward Bennett Williams, Esq., dated June 25, 1962, Appendix to Brief for Petitioner, pp. 3a-4a, Viking Theatre Corp. v. Paramount Film Distrib. Corp., 378 U.S. 123 (1964). The Department's intention was to encourage an equitable division of product in order to keep all competing theatre owners in business. 
zontal conspiracy among competitors to restrict competition. ${ }^{185}$ Rather than accepting any one of the competing arguments, the court seems to have decided the case literally on the ground that petitioner did not carry its burden of proof; if this was indeed the case, the court's decision was correct. ${ }^{130}$

In the same opinion, the court denied American Broadcasting-Paramount's Fayetteville petition. ${ }^{137}$ The Fayetteville and Poughkeepsie cases were in many particulars quite similar - the major difference being only that the split of product in Fayetteville received little or no emphasis. The court's opinion denying the petition can usefully be compared with its later opinion, entered after a rehearing, granting the petition with restrictions. In the first opinion, the denial, the court wrote:

I now turn to the proposed acquisition of the Boulder [sic: Boulevard] Drive-in Theatre in Fayetteville ... . The following persuasive objections of the Government have not been sufficiently overcome: first, the proposed acquisition will constitute a significant rise in petitioner's seating capacity in the competitive area, thus tending to confer upon petitioner a more dominant position; second, the acquisition would result in a very large potential increase in petitioner's first-run capacity; third, this likelihood of first-run dominance might well result in the effective discouragement of first-run competition by competing drive-ins; fourth, the acquisition would eliminate a potential first-run competitor; and lastly, the acquisition would restore petitioner to a favored competitive position comparable to that it enjoyed when it was subjected to divestiture. ${ }^{188}$

Two months later, after a rehearing, the same court wrote:

Two considerations have been urgently pressed by petitioner which I think justify the granting of the attached order. First, seven new theatres have been opened in Fayetteville ... since the implementation of the consent decree, thereby changing to a considerable degree the theatre situation in this community. Second, the impact of the drive-in theatre activity upon

135. The "law of splits" has developed along peculiar lines. The support upon which the dubious legality of this form of market division has been made to rest is whether or not the distributors "acquiesce" in the division of their film product by the exhibitors of a given locale. See cases cited supra, note 131. It would seem that the courts' main concern in emphasizing such acquiescence is with whether or not the distributors have been fairly treated. In any event, the law is settled that if a distributor did not consent to the split, he may recover treble damages from the "conspiring" exhibitors. Samucl Goldwyn Prods. v. Fox W. Coast Theatres Corp., 194 F. Supp. 507 (N.D. Cal. 1961) aff'd, sub. nom. Twentieth Century-Fox Film Corp. v. Goldwyn, 328 F.2d 190 (9th Cir. 1964), cert. denied, 85 S.Ct. 143 (1964). But, despite the posture of the present case law on splits, the entire inquiry into the origin of the split, and thus its legality, went only tangentially, at best, to the overall question whether the petitioner's purchase of another theatre in Poughkeepsie would restrain trade. For, as will be argued in a subsequent section, the existence of such a split of product should carry with it the presumption that the major theatres in the relevant market are competitive in the literal sense. See text accompanying notes 236-242 infra.

136. Indeed such a result is demanded by the wording of the acquisitions clauses, fixing the burden of proof upon the petitioner. See text supra note 10.

137. Both cases were decided in the same opinion; see note 124 stipra.

138. See note 124 supra. 
this situation has substantially altered the basic considerations that gave rise to the provisions of the consent decree in 1949 affecting this geographical area. ${ }^{139}$

Accordingly, it granted the petition, "but subject to restrictions which should prevent any unfair application of a first-run policy." The order, similar to the one issued in the Hamden case, restricted petitioner's operation of the Boulevard Drive-in to subsequent run, subject to exceptions whenever its competitors played first-run at their drive-ins. ${ }^{140}$

As the juxtaposition of the two opinions indicates, the decisive factor, overriding all the others mentioned, was the change in the competitive situation since the Paramount decree was written about 13 years earlier. To the question why this factor was decisive, no answer can be given. Although the affidavits and briefs filed before and after the rehearing provide some clue to the court's motivation, they do not justify its decision. In fact they make clear that competition would not have been "unduly restrained" by the purchase, and provide no basis for the highly restrictive decree which accompanied the final order.

There were 13 theatres in Fayetteville, 11 of them in operation.141 Five of these were conventional houses, and six were drive-ins. Only one of these 11 theatres was operated by a true "independent," a small (300 car capacity) onetheatre operator who was not contesting the acquisition. The remaining ten were operated by powerful circuits: American Broadcasting-Paramount, the petitioner (450 theatres), operated two of the five conventionals, one of them on first-run; H.B. Meiselman (18 theatres), a protesting amicus, operated the biggest and the best appointed first-run house in Fayetteville, ${ }^{142}$ as well as three of the six drive-ins, of which one with two screens was the largest; Stewart \&

139. United States v. Paramount Pictures, Inc, 1962 Trade Cas. 76016 (S.D.N.Y. 1962). (Hereinafter cited as Fayetteville II).

140. The order, dated March 9, 1962, read:

American Broadcasting-Paramount Theatres, Inc, or any subsidiary thereof, may operate the Boulevard Drive-in Theatre on a first-run policy provided that it shall not, in any year, operate the Boulevard ... on first-run in excess of the number of weeks that a Fayetteville drive-in competitor operates a drive-in or thentre or theatres on first-run. It is provided, however that in any year AB-PT, Inc, may play the Boulevard ... on first-run from an additional period not exceeding three weeks, but in that event AB-PT, Inc. shall not play the Boulevard . . . on first-run the following year until a drive-in competitor has been on first-run for a period equal to the additional period of the previous year and thereafter (except for the three week leeway period applicable to the current year) only to the extent that such additional period is exceeded by a drive-in competitor.

141. One of the 11, a drive-in, was operated solely as a restaurant. The data on the theatres in the Fayetteville area and the facts concerning them set out in the text were uncontested in the proceedings. The Post-Hearing Memorandum of American Broadeasting-Paramount Theatres, Inc., dated Feb. 2, 1962, and filed in the Southern District of New York on that date, has provided the primary source. The number of theatres and their ownership, characteristics, etc., appears id. pp. 4, 6 .

142. Meiselman so testified (hearing Transcript I, pp. 38, 42, 47), see Post-Hearing Memorandum, supra note 114, p. 5. 
Everett Theatres, Inc. (55 theatres) operated the two remaining conventionals, one of them on first-run; Consolidated Theatres, Inc. (then a 28-theatre chain) operated the remaining two drive-ins, of which one was concededly the "nicest" in town. The Boulevard Drive-in, which petitioner wanted to buy, was the fourth largest of the seven major drive-ins, ${ }^{143}$ and had been up for sale for some time. Amicus Meiselman had turned it down as a bad investment. ${ }^{144}$ Thus after the purchase American Broadcasting-Paramount would own one of the three first-run conventional houses, and one, the fourth largest of seven drive-ins. Its competitors were, with the exception of one very small subsequent-run operator, strong and successful circuits, all of them including the amicus ${ }^{145}$ hardly in need of the protection from competition so generously provided them by the court. In the face of such a competitive situation, it is difficult to understand the Government's opposition to the petition and the court's initial refusal to grant it. Had it not finally been granted, the Meiselman and Consolidated Circuits would have been effectively insulated from significant drive-in competition. As it was, the judicial restraint on the Boulevard Drive-in's ability to compete came close to accomplishing the same result.

\section{The Econonitcs of the Acguisitrons Cases: More Questions Than Answers}

A. Factors Considered by the Court in Passing on Acquisition Petitions Under the Paramount Decrees.

If the preceding cases leave the reader vaguely dissatisfied with their outcome; the explanation most likely lies in their economic results and the legal reasoning which produced them. It therefore seems appropriate to analyze the reasoning of the court and the Department of Justice with respect to its economic validity. Before undertaking this analysis, however, it will be helpful to identify and summarize the various factors which have led to decision in the majority of acquisition cases. To a certain extent such a listing of factors may be arbitrary and may inadequately represent all the considerations which have led to any given decision. Despite this possibility, the following description of the most frequent and important factors provides a useful shorthand manner of setting forth the foundation upon which the economic reasoning of the acquisition cases seems to rest.

\section{Population and commercial growth and movement into the surrounding area}

This factor is usually present in petitions to construct new facilities; otherwise only in exceptional cases would the circuit be interested in investing in the particular vicinity in question. It is less frequently present in cases involv-

143. It was the third largest of those in operation as drive-ins. Post-Hetring Memorandum, supra note 114, pp. $4,6$.

144. Id. p. 28. See also Affidavit of Haliburton Fales, II, Attorney for Amcrican Broadcasting-Paramount, in support of Motion for Reargument, dated Jan. 5, 1962, p. 8.

145. See text sipra at notes 141-143. 
ing pre-existing theatres, since these petitions, typically to purchase drive-ins, are generally motivated by a desire to diversify and do not depend upon market growth. The court uses growth in connection with its assessment of the competitive effect of a purchase or construction of a theatre: for example, whether the present and projected growth of an area will support additional theatre capacity.

2. The petitioning circuit's percentage of the market relative to its percentage at the time of the Paramount decrees

If the petitioning circuit had operated theatres in the relevant area prior to the Parannount decrees, the court's first inquiry has been what disposition of these theatres did the decrees make? The divestiture clauses of each decree, which forced the sale of at least one and sometimes more than one theatre in every situation where the defendant circuit monopolized first-run exhibition, attempted to make each exhibition market reasonably competitive. If the particular situation was reasonably competitive, the Paramount decrees permitted the spin-off circuit to retain all its theatres in that area. This disposition in the vicinity surrounding the proposed acquisition has given rise in the acquisition proceedings to the unstated presumption that the petitioner's market position as established by the decrees was sufficiently competitive to satisfy the demands of the antitrust laws. Consequently, the ratio of circuit holdings to independent theatres after the Paramount decrees were implemented is presumed to provide a rule of thumb by which the competitive effect of an acquisition may be judged. If the proposed construction or purchase will increase the petitioner's holdings past its percentage of total theatres in the particular area at the time of the Paramount decrees, the construction or purchase is presumptively unlawful. ${ }^{146}$ While this factor was an important reason for the denial of at least one petition, and seems to have been the cause of several others, its role is much more important in those petitions which were granted. ${ }^{147}$ In these cases the court relied heavily upon the fact that the petitioning circuit presently held considerably fewer theatres than the Paramount decrees permitted, and thus that its competitive position had weakened.

3. Petitioner's market position in terms of the mumber of theatres it controls

This factor differs from the one preceding in that it applies whether or not the petitioner owned theatres in the relevant competitive area at the time of Paramount. It is irrelevant, of course, if the petitioner is making an initial entry into a given market. But where the additional theatre will be superimposed on a circuit's existing market position, an inquiry is made to determine whether the petitioner will become the "dominant" exhibitor if another theatre is added to those presently under its control in that market.148 If such

146. See, e.g., the court's language in the Wilkes-Barre opinion denying the acquisition.

147. See, e.g., the court's language on this point in the Fayctferille II opinion.

148. It was to this point that the Government was speaking in its Mfemorandum on the Hamden acquisition, supra note 98 . All of the Representalive Cases deal with this 
"dominance" is found, it is assumed that competition will be "unduly restrained."149 The assessment is usually made in terms of straight market percentages: it is asked what percentage of the total theatres in operation will petitioner control (a) altogether, and (b) on the particular run in question?

\section{Petitioner's percentage of total seating capacity in the relevant market}

This factor, which also goes to an assessment of overall market position, appears only in acquisition cases concerning pre-existing theatres, although it is not readily apparent why this should be so. All the seats in all of petitioner's theatres in the vicinity are added together and compared to the total number of seats in the area. Like the percentage of total theatres which the petitioner operates, there seems to be a tipping point somewhere on the seating-percentage scale which when reached leads the court to hold that the proposed acquisition will "unduly restrain competition."150

\section{The location of competing theatres in relation to the theatre to be con- structed or purchased}

This factor is of very great importance in all cases. The court generally speaks of the number of theatres located within a given radius of the proposed or pre-existing theatre in the process of defining the relevant competitive market within which effects on competition are to be assessed. In the petition itself, in the supporting and contesting affidavits, and in the argument at the hearing, much effort is customarily expended in computing geographic distances and in determining from which centers of population a given theatre does, or is likely to, draw its patrons.

issue, as do many others not discussed because of space limitations. See, c.g., United States v. Loew's, Inc., 1964 Trade Cas. 80264 (S.D.N.Y. 1964) ; United States v. Loew's, Inc. (National-General), 1961 Trade Cas. 77675 (S.D.N.Y. 1961).

149. For examples of judicial language see text at notes 125-126, 138 supra.

150. The Wilkes-Barre, Poughkeepsie, and Fayelteville $I$ cases are all prime examples. The court's opinion in Wilkes-Barre, denying the acquisition, clearly illustrates the manner in which factors two, three and four work together. Factor five, to be discussed in the text infra, seems to have been thrown in merely for good measure. In Wilkes-Barre, the court wrote:

American-Paramount already owns two theatres in this area accourting for approximately $13.7 \%$ of seating capacity. . . . Petitioner's foremost competitor . . . owns five theatres and accounts for approximately 33.16 per cent of the seating capacity. The other theatres are independently owned. ...

The Government and three of petitioner's competitors have opposed the acquisition. The Court agrees with them that American-Paramount has not sustained its burden of showing that competition will not be unduly restrained. The acquisition of Midway by American-Paramount will increase the latter's percentage of seating capacity to 16.68 per cent. This figure represents a greater percentage than that held by American-Paramount when the Consent Judgment was entered, although the market has substantially declined since the date of that judgment. The combined capacity, moreover, of the two largest concerns, petitioner and Comerford [which owned the five theatres above mentioned], would increase to 50.3 per cent as another independent competitor of these two chains is eliminated. United States v. Paramount Pictures, Inc., 1962 Trade Cas. 77102 (S.D.N.Y. 1962). 


\section{Whether the petitioning circuit is purchasing a competitor}

In some cases, the absence of this factor appears as one of several reasons for granting the petition ; ${ }^{\mathbf{1 5 1}}$ and in a few instances, particularly Wilkes-Barre, Poughkeepsie, and Fayetteville $I$, the presence of this factor provided one of the reasons for denial. As might be expected, when this factor was considered, the successful petitions all involved to-be-constructed facilities, and the denials, pre-existing theatres. However, in some pre-existing theatre acquisitions, Fay'etteville II for example, the court disregarded this consideration entirely.

\section{Whether the petitioner's behavior has been anticompctitive}

This factor is considered by the court, frequently in great detail, whenever it is advanced by the Department of Justice or a contesting amicus curioe. In the cases in which it has been significant, it has been considered in all three temporal dimensions. The petitioner's past and present practices in film buying, its agreements with distributors with regard to runs and clearances, and its relations with competitors are scrutinized to determine whether they are, or have been, anticompetitive and violative of the antitrust laws. ${ }^{162}$ If so, the continuation of such relations and practices in the future in the operation of the new theatre is presumed; and the court considers this a weighty reason to find that granting the petition is likely to "unduly restrain competition."

Two caveats seem warranted, however. The cases indicate that none of the seven factors is given any particular weight in relation to the others in the court's determinations. A factor which seems decisive in one case may be accorded little or no weight in the next, with no apparent explanation. Nor can the seemingly ad hoc weighting of these factors be attributed to the factual patterns of the various cases. In addition, the factors appear and disappear from the court's opinions in a totally unpredictable manner. The court secms to treat each case as sui generis, and no case has precedential value. ${ }^{123}$ Curious-

151. See, e.g., United States v. Loew's, Inc, 1964 Trade Cas. 80264, 80265 (S.D.N.Y. 1964).

152. This factor frequently appears in the cases under the rubric "unclean hands." Typical is the Stanley Warner Corporation's acquisition in the King of Prussia Plaza, Montgomery County, Pa., United States v. Warner Bros., Pictures, Inc, 1964 Trade Cas. 79239 (S.D.N.Y. 1964). See also United States v. Loew's, Inc, 1964 Trade Cas. 79309 (S.D.N.Y. 1964). But this is an inaccurate usage of the equity doctrine of "unclean hands"; for it is a doctrine which, if properly applied, would shut the petitioning circuit out of court in liminie. See 2 PoMreroy, EQUTry Jurisprudence $91-92$ (5th ed, Symons rev., 1941). This has never happened. In practice, the court merely considers allegations of unfair competition, anti-competitive practices or "unclean hands" along with its consideration of competitive effects, and from time to time will impose a restriction upon the circuit's operation of its new theatre or other theatres in the area, in order to protect competitors against the alleged anticompetitive practices. See, e.g., United States v. Loew's, Inc. 1962 Trade Cas. 76373 (S.D.N.Y. 1962); United States v. Loew's, Inc, 1961 Trade Cas. 77675 (S.D.N.Y. 1961).

153. This type of antitrust adjudication is subject to criticism in its own right, regardless of its effects: "Even in a predominantly common law field such as antitrust the courts should not of course write afresh with each case, for the common law itself 
ly, the parties have acquiesced in this total lack of predictability, and have never attempted to analogize pending to past petitions even where the competitive situations looked identical.

\section{B. An Economic Analysis of the Legal Criteria}

As the previous discussion of the representative cases and of the seven factors that appear in them illustrates, the court has assumed that the "unduly restrain competition" standard is met if the purchase or construction is proved likely to provide the petitioning circuit with a "dominant" position in the relevant market. Although the term "dominance" appears in most opinions, the court has never explained what it means to be "dominant" in a market. Perhaps this failure of articulation is caused by a more fundamental omission - the failure in any case to define what product-line or geographic area constitutes the relevant market. With respect to determining the relevant productline, the court usually has relied upon the run - first or subsequent - which the theatre to be constructed or purchased would play, assuming quite correctly that first and subsequent run product do not directly compete with one another. ${ }^{164}$ Thus if the new theatre was to play first-run, the court's inquiry into competitive effect was usually made in the first-run product market.105 But even with so obvious a yardstick, the court has occasionally been inconsistent. In some instances, it has concerned itself with the competitive effects in all runs when only one was affected ${ }^{156}$ and in dealing with percentages of seating capacity and number of theatres possessed by the petitioner, both of them decisive factors in determining "dominance," the court has aggregated thentres playing both first and subsequent run. ${ }^{167}$

With respect to definition of the relevant geographic market affected by an acquisition, the court has opted for maximum flexibility, and consequently has created maximum uncertainty. In each case where some noises are made about the relevant geographic market, the location of the theatres considered competitive with the proposed acquisition seems to provide the starting point for the court's analysis. Sometimes this analysis is made in terms of actual lineal distance between the theatres in blocks or miles, ${ }^{168}$ and sometimes in terms of

places great value upon continuity of doctrine." Bork, The Rule of Reason and the Per Se Concept; Price Fixing and Market Division, 74 Yale L.J. 775, 780 (1965).

154. See text accompanying notes $166-170$, infra.

155. See, e.g., National Theatres' (now National General's) San Jose, Calif. accuisition, United States v. Loew's, Inc., 1962 Trade Cas. 76373-374 (S.D.N.Y. 1962). The court followed this procedure in the Hamden and Cheltenham cases.

156. This seems to have been what happened in the La Mirada case, for example, and in the Wilkes-Barre case, see discussion supra note 150.

157. Examples are the La Mirada, Wilkes-Barre, Poughkeepsie, Fayalleville, and Garden Grove cases, discussed in the previous section.

158. Rarely, if ever, has a discussion of measured distances appeared in an opinion other than in terms of fixed radii outward from the site of a proposed acquisition. But the records of the proceedings in several cases indicate that lineal distances are often 
each theatre's location with regard to the particular population centers from which it will draw its patrons. ${ }^{159}$ But, in something approaching a majority of cases, the court has given no inkling as to how it determined who competes with whom. ${ }^{160}$ The problem is further complicated by the fact that there are several important opinions in which the location of competing theatres is nowhere mentioned. ${ }^{161}$

When the relevant market has been defined and articulated in terms of the distances between the theatre to be purchasd or built and other theatres, the court has customarily made no more than a terse descriptive statement that, for example, within a 10 -mile radius there are 24 theatres. From this is drawn a conclusion as to whether the acquisition, if a new theatre, will drive others out of business, or whether the acquisition, new or pre-existing, will enable the petitioner to "dominate" the exhibition field in the area. In no reported case is there any suggestion of why a given radius was chosen. Moreover, when nothing more than a flat numerical quantity of theatres within a certain

matters of dispute; and the court takes great interest in such distances. One exchange between court and counsel gives excellent illustration:

THE COURT: I would like to be enlightened with respect to the distances you claim is [sic] between your theatre and these competing theatres.

Mr. Pecora: May I make an opening Statement?

THE COURT: I hardly think it would help me. I have read your papers ... I I know what you are going to try to prove. I told you that the only elements that concern me, at least at first blush, is [sic] the fact that there is an attacls upon the distances that you have represented to the Court.

Cheltenham hearing Transcript, supra note 67 , at p. 23 .

159. This approach is best exemplified by United States v. Warner Bros. Pietures, Inc., 1963 Trade Cas. 78800 (S.D.N.Y. 1963), a case wherein Stanley Warner was permitted to construct a 1500-car capacity drive-in theatre in Camden, New Jersey. Ficre the amici curiae were read out of court because the court determined that their theatres would draw their patronage from different population areas. The court wrote that the amici's drive-ins were

in separate and unique positions from the standpoint of their draw on Philadelphia patronage and their competitive relationship to petitioner's new theatre I cannot conclude, on the facts before me, that petitioner's drive-in would provide them with any valid ground for complaint.

Id. at 78801 .

160. In situations where the theatres on a given run often play day-and-date - that is, where multiple runs are common - this failure of articulation can be especially damaging. In La Mirada, for example, it would seem obvious that the new thestre would not compete with all first run houses within the 13-mile radius; a relatively vell-defined submarket structure must have existed. See rupra notes 57 and 108. A recent and as yet unreported, opinion, United States v. Loew's, Inc, (National General) April 6, 1965, see note 180 infra, indicates that the court is now beginning to recognize and to utilize in its decisions, the submarket structure created by distributors in establishing multiple first runs. Here the San Fernando Valley was considered the broader market, and a section lying west of the San Diego Freeway, a relevant submarket.

161. This was the case in the Wilkes-Barre, Poughkeepsie, and Fayedtcrille opinions, denying the petitions. There are also many examples in opinjons granting the petitions. See, e.g., the Hamden and Cheltenham cases. 
radius is given, without any regard to whether or not they are competitive in terms of runs and clearances with the proposed theatre, the figures are largely meaningless. Even assuming that the number of theatres was descriptive of some competitive picture, there has never been any attempt to lay down standards for fixing the length of the radius. In some cases, the relevant market has been as small as a neighborhood or section of a large city $;^{\mathbf{1 6 2}}$ in others it has been the entire city and one or more suburban communities taken together ; ${ }^{103}$ and in the remaining cases the relevant market has been an arbitrarily chosen radius of $5,7,10$, or 13 miles. ${ }^{104}$ The court's decision to consider a. 13-mile radius containing 48 theatres in the Stanley Warner La Mirada case is a graphic example of arbitrary market definition. No explanation of the 13-mile radius has ever been offered other than that the petitioner owned one other theatre 13 miles away, on the outskirts of Los Angeles. Presumably, if this theatre had been located 15 miles away, a 15-mile radius would have been chosen.

These difficulties of market definition have been compounded by the court's failure to differentiate between the two different levels of the product market - that in which the theatre operator purchases product and that in which he exhibits it to his patrons. Presumably, despite the courts' failure to so state, the market with which the antitrust laws and Paramount decrees are ultimately concerned is the patron market. For competition on all levels of film production, distribution, and exhibition is waged for the custom of the theatregoing public; and it is the patron's dollar which supplies the source of all motion picture revenues. ${ }^{165}$ Yet the court has most frequently, and almost

162. This was the market definition in the Cheltenham case. See text accompanying notes 67-85 supra, Cheltenham being a relatively small section of Philadelphia.

163. This was the market definition in the Hamden case. See text accompanying notes 91-104 supra, all of the Greater New Haven area being taken as the relevant market; in National General's Phoenix, Arizona acquisition, 1961 Trade Cas. 77675 (S.D.N.Y. 1961) all of Phoenix and the surrounding area; in Stanley Warner's Houston acquisition, 1964 Trade Cas. 80180 (S.D.N.Y.) all of Houston; and in Locw's Rocky River, Ohio, petition, 1964 Trade Cas. 80264 (S.D.N.Y. 1964) all of Cleveland and its western metropolitan suburbs.

164. See, e.g., National General's San Jose, Calif., acquisition, United States v. Loew's, Inc., 1962 Trade Cas. 76373 (S.D.N.Y. 1962) (10-mile radius); and Stanley Warner's La Mirada case. (13-mile and seven-mile radii).

165. United States v. Paramount, 334 U.S. 131 (1948) dealt almost exclusively with the first-run exhibition market, "the cream of the exhibition business," id. at 166, 173; the issue was which exhibitors would get this business. The emphasis throughout Paramount was therefore upon product licensing practices, product distribution, and the control of first-run product in the hands of the five major circuits. Yet, Paramount must be viewed as ultimately and chiefly concerned with the patron market. The reason is that monopoly has traditionally and properly been considered harmful for its effects on consumers and on the allocation of the nation's economic resources. Permitting monopoly to exist at any level in the production-distribution-exhibition chain is to sanction restriction of output and prices higher than a competitive market would otherwise have dictated. Therefore, even though the arguments in the Paramount case were pitched in terms of the film-purchasing market, consumer want satisfaction was the value at stake 
exclusively, concerned itself with the status of competition in purchasing product alone. While this is confusing, it is not necessarily incorrect. Indeed the relationship between the product-purchasing market and the patron market is one of interdependence. The economics of the motion picture industry indicate that the ability of a circuit to obtain more top quality product than any of its competitors in a relevant geographic area will enable it to dominate the patron market in that area. On the other hand, a theatre more attractive than others will act as a lure to patrons and enable the operator to obtain more easily top quality product. The important point is that the product market has a twolayered structure which must always be considered in analyzing the competitive effects of an acquisition.

Even assuming that the market definition problems can be adequately solved, the question of what constitutes a dominant position still remains. The court has assumed that dominant position can be shown by determining the petitioner's percentage of an area's total seating capacity and of its total number of theatres then in operation. There are two separate problems in this procedure. First, are seating capacity and number of theatres reliable indices of dominance? Second, assuming that they are, what percentage can be presumed, from the existing case law, to be illegal as "unduly restraining competition"? Despite ten years of active experience with litigation under the acquisition clauses, neither the Department of Justice nor the court has addressed itself to these questions.

All available evidence indicates that seating capacity is a highly unreliable factor for determining whether an acquisition will give the acquiring circuit dominance in the relevant market. In the first place, the manner in which it has been computed in all cases to date is erroneous. In Faycticuille I, Poughkeepsie, and Wilkes-Barre, for example, drive-in and conventional theatre capacities were aggregated as if seats in cars and seats in theatres vere totally fungible. This, however, is demonstrably untrue. Drive-ins are operable only at night and in reasonably good weather, and can serve only the motorized segment of the public. Such limitations are very considerable, and indicate quite clearly that the capacities of these two very different types of theatre facilities are in no meaningful way interchangeable. Additional error is introduced because present computations, even where inclusive of only one or the other type of theatre facility, have consistently neglected obvious differences in the condition, equipment, and appointments of the drive-ins or conventionals the seats of which were being aggregated. An exhibitor with two modern, wellappointed houses but with only 25 per cent of his area's seating capacity, may be in a far stronger competitive position than an exhibitor with three "dreadnaughts" containing 60 or 70 per cent of total area capacity.

in the case. On the maximization of consumer want satisfaction as an over-riding goal of the antitrust laws, whether implemented in terms of the rule of reason or the per se rule, see Bork, The Rule of Reason and the Per Se Concept: Price Firing and Mlorket Division, 74 YALE L.J. 775, 781, 805 (1965). 
Finally, it is misleading to add together the seats of first- and stibsequentrun houses. For purposes of analyzing the competitive situation in an areat, first-run and subsequent-run houses should not be treated as in the same product market, either on the purchasing level or on the patron level. With regard to the purchasing level, houses on different runs do not usually compete for the same films; only rarely, if ever, do first-run houses show subsequent-run films and subsequent-run houses, first-run films. ${ }^{100}$ The Supreme Court in United States v. Paramount Pictures, Inc. ${ }^{107}$ explicitly recognized this differentiation between the two film purchasing markets. ${ }^{168}$ In the patron market, the differentiation between runs is not so clear; however, for the purposes of analysis, it is justifiable to treat first and subsequent run theatres as not being competitive for the same patrons. This differentiation is unclear because there are a variety of intangible, and perhaps largely fortuitous, factors which create a certain degree of cross-elasticity of demand. As any moviegoer knows, his choice between runs may depend on the relative quality of the pictures in each run, and on whether or not he missed the better film on its firstrun; for this reason it is to be expected that "Mary Poppins," "Lawrence of Arabia," or "My Fair Lady," will provide on their subsequent runs far more competition to the first-run films then playing, than would more mediocre product. Other intangibles are the relative convenience of location of the subsequent-run neighborhood houses, the weather in the case of drive-ins, and the desire to see a double rather than a single feature. The importance of these considerations should not be overestimated, however, since the first-run film is at the center of the industry's publicity, and since television is taking an increasingly large share of the subsequent-run business from the theatres.

In addition, despite the non-quantifiable factors which make different runs in some degree competitive, industry distribution practice and exhibitor pricing patterns testify that this inter-run competition for the patron's dollar has been rendered insubstantial. The fact is that the patron markets for different runs have been effectively insulated from each other. This insulation of patron markets has been accomplished by the devices of runs, clearances, and exclusive showings within geographical zones; these devices effectively enforce price discrimination between runs, by making the patron wait a considerable time

166. Several qualifications of this statement are in order. Changing a theatre's run position from time to time is not unknown. By renovation and the requisite increased investment, a subsequent-run house with a good location and adequate parking, can easily be moved up to first-run. Moreover, in periods of severe shortage of quality firstrun product, first-run theatres are known to play superior second-run film. Finally, among less competitive houses playing on multiple first or subsequent runs, some shifting of playing position is common. The explanation offered has usually been that not all films are suitable for multiple showings in day-and-dated theatres. Hence, from timo to time, a product shortage develops in such areas. But these are minor qualifications, and have traditionally been disregarded by the courts and the industry at large.

167. 334 U.S. 131 (1948). *

168. See discussion of this point supra, note 165 . 
or travel a considerable distance if he wants to pay less to see the same film. ${ }^{160}$ The effectiveness of this insulation between runs is amply demonstrated by the pre-Paramont history of the exhibition industry. This history indicates that the exhibitor defendants only were interested in monopolizing the first-run exhibition market. Their tactics and behavior proved that the most knowledgeable operators in the industry were convinced that it was unnecessary to achieve similar control of the subsequent-run exhibition market to obtain the advantages of monopoly. ${ }^{170}$ Thus, although the patron market cannot be absolutely divided according to runs, aggregating a circuit's seating capacity irrespective of runs will only fortuitously reflect the circuit's actual competitive stance in the relevant geographic market.

Even without errors in computation, however, a seating capacity percentage figure is totally irrelevant to any rational consideration of an additional theatre's competitive impact. With regard to the market in which films are purchased, this conclusion is immediately evident when it is remembered that product must be offered by each of the major distributors, all of whom were defendants in the Paramount case, no other way than theatre-by-theatre, filmby-film, pursuant to the Paranount injunctions. ${ }^{171}$ Since he is not given the opportunity, a multi-theatre operator is preyented from aggregating his total seating capacity on any particular run in one bid. For this reason, what counts is the seating capacity of the individual theatre for which a particular film is being sought. In any case, no exhibitor would desire to play the same film in more than one of his theatres unless they were in different competitive markets.

But even if the seating capacity of two or more theatres is not aggregated, and dominance is found in the seating capacity of the additional theatre, that is, by a one-to-one comparison of the petitioner's theatres with those of the competitors, this finding would contribute little to a determination that the theatre to be constructed or purchased will "unduly restrain competition" in the product market. Although the court has never explained the significance of seating capacity as such, the unarticulated premise must be that the ex-

169. Conant 58-61, 65-69, passim.

170. Id. at $61-69$, passin. Because of the run and clearance structure throughout the country prior to United States $v$. Paramosmt, the defendants channeled 30 to 70 per cent of all rentals into first run. In Chicago and Washington, D.C., the figure was between 35-50\%, and in Atlanta, it was 70\%. Id. at 66-68.

171. Typical of the injunctions running against the Paramosnt defendants is the following, taken from the Warner Consent Judgment:

The defendant Wamer Bros. Pictures Distributing Corporation, its subsidiaries in which it has more than a fifty per cent interest, its successors, its officers, agents, servants and employees are each hereby enjoined:

7. From performing or entering into any license in which the right to exhibit one feature is conditioned upon the licensee's taking one or more other features.

8. From licensing any feature for exhibition upon any run in any theatre in any other manner than that each license shall be offered and taken theatre by theatre, solely upon the merits and without discrimination in favor of affiliated theatres, circuit theatres or others.

Warner Consent Judgment, III (7) and (8), supra note 8. 
hibitor with the largest number of seats will be able to outbid his competitors. Seating capacity, to a distributor, however, is never the sole criterion of an acceptable bid; other factors have equal and frequently greater weight. Offered dates of showing - known in the trade as the exhibitor's availability - length of run promised, amount of clearance over competitors desired by the exhibitor, percentage of gross receipts offered, and the parking facilities and physical appointments as well as the location of each theatre, are included in the distributor's evaluation of every bid received. ${ }^{172}$ Although these considerations will have varying weights depending upon the nature of the film and the particular segment of the movie-going public at which the product is aimed, it is obvious that seating capacity by itself can only be determinative when in the subjective judgment of the distributor all other considerations are equal or nearly equal - definitely a rare occurrence. Thus, for example, in the Cheltenham situation, the 800 seat Yorktown could have outbid the 1200 seat Erlen by offering a longer run, assuming contrary to the facts in that case that all other things had been equal. Similarly, for particular types of movies, aimed at college communities for example, a theatre location near a college may cancel out a more distant competitor's otherwise insuperable seating advantage.

The above criticism of the seating capacity factor has dealt exclusively with the market in which film is purchased. Seating capacity, as a factor in dominance, is equally fallacious when applied to the patron market, since both markets are entirely interdependent. The court has apparently assumed that the number of seats a circuit possesses will determine in a rough way its share of the revenue from ticket sales to theatre patrons, that is, its share of an area's total theatre patronage. A theatre chain, however, is dominant on paper alone, regardless of how high a percentage of total seating capacity it possesses, if it cannot fill those seats with patrons. A circuit may control 75 per cent of an area's empty seats, but if some or all are in poorly equipped, poorly located, old and out-dated theatres, the circuit will be unable to attract top quality product from the distributors and therefore be unable to obtain anything near 75 per cent of the patron market. The remaining 25 per cent of capacity may be in the hands of theatre owners operating competitively superior houses. This is exactly what happened in Philadelphia, where the Stanley Warner Circuit, after the divestitures required by the Paramount decrees, controlled 54 theatres, giving it a decidedly dominant position in terms of seating capacity. Yet, instead of overpowering its competitors, it was forced by the competitive shellacking it received to close or sell 35 of these houses in less than ten years. ${ }^{173}$

172. The Supreme Court took special notice of this complexity in the evaluation of bids, and for this reason refused to force competitive auction bidding on the industry; it was simply too complicated for the judiciary to police. United States v. Paramount Pictures, Inc., 334 U.S. 131, 162-63 (1948). Small theatre size can in fact be an advantage. See text accompanying notes $193-198$ and note 197 infra.

173. Stanley Warner inherited from its parent, Warner Bros., 65 theatres in the City of Philadelphia. It was required to divest 11, leaving 54, and of its own accord sold, 
There is yet another serious debility to the empty-seat capacity factor; it ignores rate of turnover. Very often one of the largest and nicest of a circuit's houses in a competitive area will be used for long-term road-show exhibitions like "My Fair Lady," tying up that house on a reserved seat, one-or-two show a day basis. Meanwhile, a major competing theatre may draw two or three times as many patrons in a single day - especially on weekends - by showing its films four or five times daily.

It follows, from this analysis that empty-seat capacity must be viewed very differently depending upon the market under discussion. Although empty seating capacity is a significant factor, albeit only one of several important factors, in the film-purchasing market, it is deceptive in the patron market. For these very. same reasons, the correct yardstick of patron-market share must be the petitioning circuit's percentage of the number of seats actually filled in a given time period. In other words, the decisive factor should be the petitioner's present percentage of total theatre attendance, ${ }^{174}$ and an estimate of the amount by which this percentage is likely to be increased by the purchase or construction of an additional facility.

When such an approach is taken, yet another conclusion appears inescapable: the measure of a circuit's dominance based upon its percentage of the total theatres operating in the relevant competitive area, is similarly erroneous. Since the decisive factor in determining a circuit's share of the patron market must be its percentage of the total theatre attendance over a given period of time, the number of theatres operated by the circuit in the relevant geographic market is immaterial. The experience of the Stanley Warner Circuit in Philadelphia after the Paramount decrees provides irrefutable testimony in support of this proposition.

Use of a circuit's total number of theatres in a relevant geographic market to determine dominance in the film-purchasing market is equally without foundation, although here the explanation lies not in motion picture economics but in the governing antitrust law. All the major distributors and the four spinoff circuits are bound by the Paramtomnt injunctions, banning "circuit buying"

closed, or permitted the lease to expire on 35 additional houses. United States v. Warner Bros. Pictures, Inc. (Cheltenham), 1960 Trade Cas. 77397 (S.D.N.Y. 1960); (King of Prussia), 1964 Trade Cas. 79239 (S.D.N.Y. 1964). There has been some diserepancy" in the exact figures; the author has been assured, however, that the above figures are correct. Interview with Mr. Stuart Aarons of the office of the General Attorney, Stanley Warner Corp., in New York City, April 9, 1965.

174. By this is meant paid admissions. Stanley Warner (SW) used these figures quite effectively against amicus Ellis who was contesting SW's Cheltenham acquisition. See text accompanying notes 67-85 sipra. In this case SW clearly proved that the Ellis Circuit was the most successful exhibitor in the immediate area, with 265,000 paid admissions at its Erlen theatre, which was on first-neighborhood run, and 135,000 paid admissions at its Renel theatre, which was on subsequent run, during the previous year. Stanley Warner's Yorktown, in the meantime, only had 154,304. Petitioner's Nremorandum on the Facts, United States v. Warner Bros. Pictures, Inc. (Cheltenham), supra note 67, p. 11. 
and requiring that film product be offered by the distributors on a film-by-film, theatre-by-theatre basis. Therefore, in any given competitive situation, only one of a circuit's theatres can compete or negotiate for a particular film. Thus existing competitors of an acquiring circuit will not be forced to bid against all of that circuit's theatres in the relevant area. Rather, the competitive siturtion, in terms of the number of houses competing for any specific picture, will remain the same after the purchase or construction; one theatre - perhaps the new one - will still compete with one theatre of each of the circuit's competitors. It seems to follow that if a petitioner has at least one strong and viable competitor in the field able to deprive it of quality product, the petitioner, regardless of how many houses it may operate in the same market, should not be considered "dominant," whatever this term may mean. In such a view, number of theatres is as meaningless as seating capacity. Both rest upon premises unfounded in either the industry's economics or the rules of law presently governing its operation.

If the above criticism of the factors used to determine dominance are temporarily disregarded, and inquiry is focused on the next step in legal analysis - determining the percentages of total seating capacity and number of theatres which presumptively give a circuit dominance - the court's performance remains highly unsatisfactory. Whether there is any particular percentage which is presumptively illegal, what that percentage is, and when it will be determinative, has remained a mystery. Each case seems to have been treated sui generis and inconsistencies between individual petitions have been disregarded. In Wilkes-Barre the court specifically found petitioner's possession of 16.68 per cent of seating capacity too great when viewed alone, and especially damning when viewed in connection with its leading competitor's 33.16 per cent of capacity. ${ }^{175}$ In Fayetteville $I I$, however, the petition was finally granted, albeit with restrictions, even though petitioner thereby obtained 23.61 per cent or 27.85 per cent of capacity in the area, depending upon whether the petitioner's or the Government's statistics are accepted. ${ }^{170}$ In other cases,

175. See note 150 supra.

176. Fayetteville II, Affidavit of Haliburton Fales, II, Attorney for American Broadcasting-Paramount, in support of Motion for Reargument, Jan. 5, 1962, p. 4.

The only difference between Wilkes-Barre and Fayelteville II is that the court found in the latter that petitioner's capacity since the date of the Paramount decrees had decreased in relation to its competitors, while in Wilkes-Barre petitioner's capacity had increased. If this is offered as a means of reconciling the cases, it must surely fail, for it does not explain why $16.68 \%$ of capacity in one market is illegal while 23 to $27 \%$ of another is not. To say without more that a percentage of a local market - defined in terms of seating capacity - greater than that which was permitted by the decrees is presumptively illegal for all time to come, is merely to raise the same question at one step removed: why should this presumption be accepted when it conflicts with results considered permissible in other cases? But, more important, the final theatre disposition in any local market provided by the Paramount decrees should be rejected in toto as a valid indicium of legal market share. For the divestiture clauses of the decrees which rearranged circuit holdings in scores of towns and cities paid no attention 
similarly high percentages were also apparently legal. Recently, for example, the court approved without restriction three petitions giving American Broadcasting-Paramount roughly 32 per cent of a competitive area's total capacity, ${ }^{177}$ and well over 50 per cent of that in two other areas. ${ }^{178}$ Similar irreconcilable conflict appears between the cases where the court was concerned with the number of theatres which a petitioner operated in a given competitive area either on a particular run or on all runs. In the Hamdens case control of two out of five theatres on first-run was considered too many, and in Cheltenham two out of four. Yet American Broadcasting-Paramount was recently permitted to build a sizable two-auditorium theatre in Gainesville, Florida, and another in Chattanooga, Tennessee, despite the fact that both acquisitions would give it two of the four first-run theatres in each community. 170 The

whatsoever to percentages of seating capacity or of total theatres held by a defendant circuit. The decrees were addressed to opening up "closed" or monopolized towns and in pursuance of this objective required a theatre or two to be divested. See note 207 infro. Whether a town was competitive or closed was decided in strictly pragmatic terms: vere there other competitive theatres which would supply alternative outlets for exhibition? What percentage of seats these competitors held was not considered relevant.

177. The first of these is located in Gainesville, Florida. Petitioner proposed the construction of an 1100-seat conventional theatre to play first-run. It also owned the 1,035-seat Florida theatre which met major first-run competition only from the State, an old 826-seat theatre. The Rose, a 573-seat Negro theatre, a 450-car drive-in, and a 400-car drive-in also played first-run, but only intermittently. The Wometco theatre chain was then building a 1200-seat first-run house 0.8 miles from the new site. United States v. Paramount Pictures, Inc., Petition Feb. 19, 1965 (no opinion; order unreported) (hereinafter cited as the Gainesville acquisition). If the traditional industry figure of 2.2 persons (seats) per car is used, petitioner would have 2135 seats of 6604 seats on all runs, or $32 \%$ of total seating capacity. If conventional theatres alone are included, then American Broadcasting-Paramount would have 2135 seats of 4734 , or $45 \%$ of conventional (four-wall, closed-in) capacity. Of first-run capacity the figure is even higher. Wometeo appeared as amicus curiae, contested vigorously, and lost. Gainesville acquisition, Hearing Transcript, Feb. 25, 1965, (S.D.N.Y.), p. 29-36; Gainesville acquisition, Order (Eranting petition), Feb. 26, 1965 (no competitive restrictions).

178. One of these areas is Clear Lake City, Texas, a NASA and aeronautical industry site midway between Houston and Galveston (area population 78,000). The order was granted from the bench. Gainesville acquisition, Hearing Transcript, ripra note 177, at p. 8. There was only one other competitive theatre in the area, the Gulf-way Drive-In, Id. p. 6 . and the area had a projected population of 214,000 by 1970 and was thus a rather significant exhibition market. Id. p. 4.

The other competitive area was Chattanooga, Tennessee. The theatre was to have 800 seats and be constructed in the "moderately growins" suburbs of the city, past Missionary Ridge. Id. p. 13. Petitioner then operated one of ten theatres in Chattanooga, and one of the three first-run theatres. Thus, the acquisition gave it two of four first-run houses, or $50 \%$ of the first-run market. It may be significant that a single circuit, Martin Theatres. Inc., [140 theatres throughout the South, Ficar DaIry Yenrcoor of Morros Picrures 1064 (1964)], owned the remaining nine theatres in town. Id. p. 14. Thus if an oligopoly figure is used (adding the petitioner's market share to that of its major competitor), as it was used in Wilkes-Barre, (see note 150 sipra) the resulting figure would be $100 \%$. This case is totally inconsistent with the Wilkes-Barre opinion. The petition was granted from the bench. Id. p. 20 .

179. See notes 177 and 178 , supra. 
cases admit of only one conclusion. By speaking of dominance in terms of percentages of seating capacity and number of theatres without attempting to render the results consistent from case to case, the court has created the illusion of a standard where none in fact exists. ${ }^{180}$

\section{Preventive Anti-trust Gone Astray: Judicial Prevention of CoMpetition}

Even were seating capacity and number of theatres reliable and consistent indices of "dominance" in a market, the bounds of which were properly defined,

180. It would seem that there are other factors, such as dynamic population and commercial growth in a given competitive area, which will render percentages of seating capacity or of total theatres in operation otherwise illegal quite innocuous, or otherwise permissible too great to be allowed. The difficulty is that the court has never bothered to articulate its reasons for ignoring market percentages or factors which would otherwise establish illegal dominance. This problem is complicated by the general paucity of opinions.

A very recent case, National General's petition to build a new conventional theatre in a large shopping center in Canoga Park, California, totally conflicts with all prior cases and illustrates the complete absence of any guidelines for the court and the parties. Yet, the result seems correct under the standard suggested by this Comment. Sec text following note 232 infra. In this case, the court allowed petitioner to build a theatre despite the fact that the new facility would give National General six of 17 first-run conventional houses in the relevant geographic market, the San Fernando Valley. In fact, the court even conceded in its opinion "that the Government's claim that petitioner occupies a dominant position is not ill-founded." United States v. Loew's, Inc. April 6, 1965, p. 8 (unreported) (hereinafter cited as Canoga Park). Two opposing factors, however, outweighed this concession; first, that the competitive area involved was undergoing rapid growth, (it is 30 miles from downtown Los Angeles) and second, that there was a concurrent increase in competitive moving picture theatres. Ibid. The court may have also relied on the fact that petitioner's seven theatres (including one drive-in) would competc with 19 other theatres (including one drive-in) on first-run either part or full-timc, id. at 6 , that petitioner's seating capacity since 1951 had fallen from $17 \%$ to $13 \%$ of the total due to new construction, that multiple first-run showing was the distribution pattern, and that there was within one and seven-tenths miles from the site a new 1400 seat Stanley Warner theatre to offer strong competition. Id. at 2 . If the last factor alone is considered, the opinion is undoubtedly correct, since petitioner's next closest theatre was ten miles away. Id. at 4. See text following note 232 infra. The Canoga Park case, however, resulted in an order which took away what the opinion had given. At the instance of the Department of Justice the court restricted National General's (NG) entire San Fernando Valley operations. The Order, filed in the Southern District of New York on May 3, 1965 (unreported) prohibited NG's nine theatres, including the new one, from playing first run in any calendar year the product of the seven major companies and Butena Vista for more weeks than the present eight NG theatres in the area played first run in 1964. Provision for judicial relief from the restriction was conditioned on a "substantial" change in distribution patterns in the Valley or on a showing of "substantial" prejudice to the new theatre's operations. National General did not consent and litigated to the finish. Despite the highly restrictive order neutralizing the liberality of the opinion, the latter is significant because it shows the "dominance" concept to be merely another factor like several others, and illustrates the absence of any settled, predictable, approach to determining if an acquisition will "unduly restrain competition." It is one of the court's best opinions, nevertheless, because it articulates the court's reasons for permitting the acquisition despite the presence of factors rendering similar petitions fatally defective. 
the concept itself should be discarded. The results in many cases, of which Cheltenham, Hamden, and Wilkes-Barre are illustrative, have been highly undesirable. Competitors not competition have been protected and trade has been restrained. The court and the Department of Justice have gone astray because the dominance concept emphasizes the strength and advantages of the petitioning circuits, and limits the Department's and the court's inquiry to whether the petitioners will dominate a local exhibition market, instead ot emphasizing the strength of existing competition in that market.

With the exception of the cases in which petitions have been granted without restriction, it is difficult to find an instance in which the Justice Department's and the court's approach to these petitions did not result in the insulation of certain competitors from the rigors of competition. The role allowed the amici curiae in these cases is a partial explanation of these results. During the last half-century, the role of the amicus curiae has been enlarged, especially on the appellate level. The role now includes taking the side of one of the litigants, commenting on the factual situation in the case, making clear the implications and ramifications in the social, political or economic sphere of any particular rule of law, and voicing an opinion as to the validity of the various contentions raised by the parties in interest. ${ }^{181}$ But appearing in the trial court and presenting evidence in the form of testimony or affidavits, for the purpose of disproving or attacking the validity of a party's case has never been permitted; this is the domain of the intervenor. ${ }^{182}$ While the court and the Justice Department have verbally supported these traditional limitations and the policies behind them, their actions lead one to suspect the depth of their commitment. The Justice Department often seems reluctant to take any position in these cases before consulting with the amici, ${ }^{183}$ and the court has permitted

181. Krislov, The Amicus Curiae Brief: From Friendship to Adrocacy, 72 Yale L.J. 694, 703-04 (1963). See generally, Krislov, supra, for the point that the amicus' role has been expanded to permit broad class and group interests to be heard at the appellate level, when a decision in a private suit will materially affect their welfare. The entire rationale which supports this expanded role for the amicus at the appellate level is inapplicable at the trial level.

182. See 4 Moore, Federal Practice if 24.02-.05, 24.16 at 108-20 (2d ed. 1963). The intervenor, precisely because he is a party in interest, is expected and permitted to introduce evidence and contest that introduced by the other parties; and quite properly; if the other parties do not meet and overcome the intervenor's case, they lose. In the acquisition cases, the amici have been permitted to introduce their own evidence, and the petitioning circuits are expected to meet it; affidavits fly back and forth; sometimes the testimony of amici is taken. In these respects, the amici are playing the role of intervenors.

183. The Stanley Warner Hamden petition was typical. The Department consulted at considerable length with counsel for the competing theatre owners, and the resulting decree, text at notes 101-105 sipra, was written during such consultations. Intervicws with Mr. Maurice Silverman, Attorney, U.S. Department of Justice, Antitrust Division, in Washington, D.C., June 15, 1964, and Mrr. Monroe Stein, counsel for amicus Bailey, in New York City, May 16, 1964. See also Mr. Silverman's report of his conference with counsel for amicus Lincoin theatre concerning protecting it from the new theatre, Hamden Hearing Transcript, supra note 93 at pp. 67-68. 
these same amici to introduce evidence of petitioner's anti-competitive practices and of the dire effects on their theatres should the petition be granted.18 Even worse, the court has considered this evidence, weighed it, and sometimes, finding it credible, has acted upon it. ${ }^{185}$ With the exception of the right to subpoena documents and witnesses, to cross-examine, and to appeal, the competing theatre owners have obtained the status of intervenors, sub nomime amici curiae. As a result each acquisition case in which amici are active has become a private antitrust suit in miniature, often culminating in a decree designed specifically to protect the protesting amici regardless of the effect on competition in the market as a whole. ${ }^{186}$

It would be inaccurate and unjust to imply that the court is unaware of the ever-present danger that the acquisitions clauses of the Paramount decrees will become instruments for suppressing competition in the name of preserving competitors. Rather the contrary is true:

In view of the very vigorous activity of the amicus curiae in this case, I feel constrained to add that the consent decree was not intended to provide other exhibitors with immunity from competition. It is the public's interest in free competition which is sought to be vindicated by the consent decree. ${ }^{187}$

The primary responsibility for suppressing competition must be laid at the door of the Justice Department, often the initiator, after conference with the lawyers for the amici curiae, of the most blatant competitive restrictions. As the court wrote in Cheltenham:

184. The Representative Cases described in part III, supra, provide illustration. See, e.g., text accompanying notes 107-111 supra (Garden Grove); in the Poughheepsie case amici's assertions that American Broadcasting-Paramount controlled its divestee illegally may have been decisive, see text, supra accompanying note 132. In National General's San Jose, Calif. case, the court devoted two and a half pages of reported opinion to the amici's contentions and evidence. See San Jose opinion 76374-76.

185." This seems to have been what happened in the Garden Grove case, since the Government did not introduce evidence or otherwise oppose the acquisition. Sec text accompanying note 107 supra. Certainly, the court gave the amici's extensive evidence in the San Jose case considerable weight.

186. The court's opinion in National General's Phoenix, Arizona acquisition, Unitcd States v. Loew's, Inc. (National General), 1961 Trade Cas. 77675 (1961), is particularly damning in this regard. Here the amici curiae barraged the court with evidence of petitioner's anti-competitive practices and "unclean hands." See depositions of Mr. Bert Plrosh, counsel for five owners of eight competing theatres, filed Jan. 28, 1961 in the Southern District of New York, on file in Antitrust Division's Paramount Docket. The court's opinion stated

After diligent examination of the relevant facts, the Division has found no merit in the challenges raised by competing exhibitors. However, to protect the independently operated drive-in theatres from any possible competitive disadvantage with respect to the licensing of first-run product, the Division has suggested a number of restrictions on National's operations which the petitioner has agreed to accept. (Emphasis added).

United States v. Loew's, Inc., supra at 77676.

187. United States v. Warner Bros. Pictures, Inc, 1960 Trade Cas. 77397, 77398 (S.D.N.Y. 1960) (Cheltenham). 
[T] he order which has been submitted to me by the Petitioner contains a number of restrictions suggested by the Attorney General and which the Petitioner has agreed to accept. These restrictions are designed specifically for the protection of the amici curiae. They are given protection from key run competition which they would neither have nor be entitled to if an exhibitor not subject to the decree were erecting the theatre. I regard the restrictions as more than ample to protect the legitimate interests of the amici curiae . . . 188

Concededly, these restrictions did not meet the acid test of litigation, as they rarely do in these proceedings; the circuits generally acquiesce, as in Creltinham, Hamden, and Fayetteville, out of fear of prolonging the litigation or losing the support of the Justice Department. ${ }^{180}$

The court, however, does not itself have totally clean hands. In La Mirada, it was the Justice Department and the petitioner in favor of wide open competition, pitted against the amici, who naturally favored some sort of judicial protection, and the court, which expressed its sympathetic attitude from the bench during the hearing:

THE COURT . . . but it strikes me that where an area is saturated with movie theatre services, if indeed it is, . . . then it seems to me that . . . the advent of a new, large, first-run theatre can possibly have disastrous effects upon the already existing .... situation to the point that it might eliminate considerable competition, not stimulate it, not preserve it, and it is that aspect of this petition which concerns me.

To give you an example which is perhaps ridiculous, but which points up what $I$ am trying to say in another area of business, there is a resort colony not too far away from New York City on an island. Up until not too long ago there were about six or seven independent green grocers there, each one making a living of sorts. Suddenly, a supermarket chain ... decided to establish a supermarket right in the middle of the island.

The supermarket was established, and automatically all of the green grocers went out of business, and they were all working as clerks in the supermarket. ...

But that is what I mean. That is, of course, a different kind of business, and the proportions are exaggerated, but this is what I am trying to say when you refer to the fact that the advent of a large new business can sometimes eliminate competition and not stimulate it. ${ }^{100}$

The Department of Justice had approved the construction at the hearing, despite the fact that it might have resulted in the demise of a competitor, and it was at that position that the court's fire was directed. After reflecting on the court's attitude, Assistant Attorney General Loevinger, on behalf of the Department, changed his mind and filed a memorandum approving the court's analysis:

188. Ibid. See also the court's opinion excerpted in note 186 supra.

189. Interviews with counsel for the various petitioning circuits have developed this reason, and the author is convinced that no other explanation can be adduced, since the counsel interviewed were all strongly opposed to the restrictive decrees with which their clients were saddled.

190. La Mirada Hearing Transcript, note 52 supra, pp. 47-49. 
Heretofore, the Government has generally opposed these acquisitions only where local domination by the acquiring circuit has been threatened. However, we do not urge that this is the only proper test, and if the Court believes that this acquisition will threaten the continued existence of one or more of the competing independent theatres, we believe that it may properly withhold its approval. ${ }^{101}$

Since Loevinger's resignation the Department has been backing away from this position, although its retreat has not been complete. Whether the court has itself tempered its concern for the survival of individual competitors is speculative, since no acquisition case involving a degree of competitiveness similar to that present in the La Mirada market has since arisen. But in any event, whether tempered or full-blown, preoccupation with a competitor's fate at the expense of the competitive process itself is indefensible..$^{102}$

The most damaging criticism lies in limine : if the "green grocer" of the exhibition market is an efficient and aggressive competitor, he does not need protection. That a theatre operator is "small," in terms of either the number of theatres he owns or the size of his theatres, does not mean that he is at a serious competitive disadvantage. On the contrary, these very factors may make him a more formidable competitor. Because his theatre, usually 600-800 seats, and his managerial force are small, the small local exhibitor operates with a lower overhead per theatre and thus can give the distributor a very high percentage of box office gross and still make a significant profit. Numerous examples are available; three, however, should suffice. In February, 1965, Stanley Warner was permitted to build an 1100 seat conventional shopping center theatre in Akron, Ohio. A Mr. Rabb, a small local operator who had just built a 614 seat house about a half-mile from the shopping center site, appeared as amicus curiae and objected at the hearing that the new theatre would put him at a disadvantage in bidding for product. ${ }^{103}$ Both the coturt and the Government supplied answers which not only rebutted this amicus, but also undercut many of the court's earlier opinions :

191. La Mirada Post-Hearing Memorandum of the United States, p. 2, supra note 52.

192. [I]t is the essential mechanism of competition and its prime virtue that more efficient firms take business away from the less efficient. Some businesses will shrink and some will disappear. Competition is an evolutionary process. Evolution requires the extinction of some species as well as the survival of others. The business equivalents of the dodoes ... are in for a bad time - and they should be. Bork \& Bowman, The Crisis in Antitrust, 65 Colum. L. Rev. 363, 375 (1965). The very economic justification for competition - the maximization of consumer want satisfaction, and thus the creation of greater wealth - is frustrated when competition is prevented by private collusion or judicial fiat in order to preserve small, inefficient competitors. Bork, supra note 165, at 831-32. Even Professors Bork and Bowman's severest critics, Professors Blake and Jones of Columbia Law School, do not dispute this point. Indeed, they write: "The idea that small business is entitled to protection simply because it is small business is a corrosive force that has been a threat to antitrust from the beginning." In Defense of Antitrust, 65 CoLun. L. Rev. 377, 398 (1965).

193. Hearing Transcript, p. 13, United States v. Warner Bros. Pictures, Inc. (Akron acquisition), February 26, 1965, opinion and order unreported [hereinafter cited as Akron acquisition]. 
THE COURT : Sometimes the 1100-seat house has a harder time in their bidding than small houses because of their tremendous overhead. It does not always follow because of the greater number of seats the more advantageous the bidding position is. 104

MR. SILVERMAN (Justice Department): Now with respect to Mr. Rabb's problem, the motion picture distributors are under an injunctive obligation to give his theatre a competitive opportunity to license pictures on first-run. Now, this means that if the Village is a suitable theatre, . . . and I presume it is a modern theatre, the distributors would have to give it the competitive opportunity I have been referring to.

With respect to the size of the theatre, it is true that sometimes a theatre of 618 seats bidding with respect to a particular picture might be at a disadvantage. It is not entirely a disadvantage to be smaller, as your Honor pointed out, since sometimes a smaller theatre can win a picture by virtue of being able to offer the distributor a longer run than the larger theatre can offer. ... Also, sometimes ... . overhead factors enter in the licensing of a picture. For example, pictures are frequently licensed under so-called 90-10 bases, where the distributor and exhibitor agree on an overhead figure, and then that comes off the top, and whatever is left goes 90 per cent to the distributor and 10 per cent to the exhibitor. And sometimes, and quite frequently, a smaller theatre which has a lower overhead has a distinct advantage in endeavoring to license a picture of that sort. So it is a combination, the smaller size is a combination of advantage and disadvantage. ${ }^{105}$

The smaller theatre operator's competitive advantage is not merely theoretical. One of the most famous small theatre success stories in the industry is that of the Arcadia Theatre, on 16th and Chestnut in Philadelphia. Arcadia, owned by an operator independent of the major circuits, was on subsequent run until 1950 when the Paramount decrees required theatre-by-theatre bidding to be initiated. At that time the Arcadia's owner, a small chain operator, bid $90-10$ over his house overhead of about $\$ 2650$ per week, and took some of the finest first-run product from the Stanley Warner and Goldman circuits, whose houses were Philadelphia's first-run palaces. Warner's Mastbaum (4387 seats) and Stanley (2932 seats) respectively had overhead expenses four and three times that of the Arcadia, and Warner's Stanton Theatre (1373 seats) was twice as costly to operate as the Arcadia. Goldman's similarly large houses were equally at a disadvantage. Today, the Arcadia is still one of Philadelphia's leading first-run theatres. ${ }^{196}$ In Washington, D.C., a similar situation prevails. There the Towne Theatre with 800 seats outbids the much larger Stanley Warner, Loew's and RKO theatres. The operator of the Towne is very small,

194. Ibid.

195. Id. at 16-18.

196. All of the information in the text concerning the Arcadia Theatre was supplied by Mr. Stuart Aarons, Office of the General Attorney, Stanley Warner Corp., telephone interview, April 28, 1965, New York City. This information and that in the note following is contained in abbreviated form in Mrr. Aarons' letter of the same date to the Yole Low Journal, on file in the Yale Law Library. For verification of the size of the Areadia Theatre, see Brief for Petitioner, Viking Thealre Corp. v. Paramount Film Distributing Corp., supra note 131. 
owning only three theatres, two of them neighborhood houses. Nevertheless, by offering 90-10 over a small house expense, he has been able to obtain for the Towne Theatre, on first run, such pictures as "To Kill a Mockingbird," "Charade," "Irma La Douce" and "A Shot in the Dark," all of them among the leading box office attractions of 1963-64.197 The small competitor, then, if he is efficient and if he operates an attractive modern facility, is not at all comparable to the local "green grocer" who could not hope to compete with the supermarket chain. Indeed, the small exhibitor can and does give the national chain exhibitor a competitive licking in many bidding situations. The inefficient small operator, with out-of-date and unattractive facilities is another matter. Protecting him is indefensible; merely to state the proposition should be enough to destroy it. ${ }^{188}$

Regardless of whether the small exhibitor actually needs the court's protection, and considering only the philosophy of an approach which seeks such a result, it becomes apparent that this approach to antitrust enforcement represents a choice of policy in search of a rationale. The commandment of the acquisition clauses requires the court to keep competition from being "unduly restrained." There can be no justification for assuming that this clause requires that the competition be between small corporate units rather than large ones. Genuine competition between large theatre chains can be as beneficial to the public and to the economy, if not more so, than competition between smaller units. The fact that the wave of modern theatre building sweeping the country was initiated, and is now being led, by the larger local, regional, and national circuits is convincing testimony to the validity of this proposition. Unless the size of a firm approaches the legal or economic bounds of monopoly, or unless it has been used in a predatory manner, size alone is no offense to the antitrust laws. ${ }^{199}$

The La Mirada case, where the court made its remarkable "green grocer" speech, moreover, did not involve the purchase of a smaller competitor; it was a clear case of internal expansion by construction of a new facility. This type of industrial growth, above all others, has always been favored by the antitrust laws. Even in Brown Shoe Co. v. United States, 200 the case often criticized as the Supreme Court's most anti-competitive venture, internal expansion was singled out by the court for approval:

Internal expansion is more likely to be the result of increased demand for the company's products and is more likely to provide increased investment

197. Letter from Mr. Stuart Aarons to the Yale Law Journal, sitpra note 196, contains all the data given in the text. If a quality film is defined as one earning over $\$ 1$ million at the box office, see note 209 infra, then each of the films listed is of superior quality: "To Kill a Mockingbird" $(\$ 7,200,000)$, "Charade" $(\$ 6,150,000)$, "A Shot in the Dark" $(\$ 6,500,000)$ Variety, Jan. 6, 1965, p. 39.

198. See note 192 supra.

199. See United States v. Aluminum Co. of America, 148 F.2d 416, 430 (2d Cir. 1945); United States v. Swift \& Co., 286 U.S. 106, 116 (1932); United States v. Unitcd States Steel Corp., 251 U.S. 417, 451 (1920).

200. 370 U.S. 294 (1962). 
in plants, more jobs and greater output. Conversely, expansion through merger is more likely to reduce available consumer choice while providing no increase in industry capacity, jobs or output. 201

If the new plants or facilities drive less modern, less efficient, or competitively inferior plants and facilities out of business, this should be approved, if not favored and encouraged, for it is the very essence of healthy competition. $0^{302}$ Any attempt to protect smaller inefficient competitors must result in an economic cost to society.

Stanley Warner's Hamden, Connecticut, acquisition provides an excellent example of the values at stake. Here, Stanley Warner sought to construct a facility better able to serve the movie-going public of the Greater New Haven area than any existing theatre. It would be the only theatre in town with totally adequate parking facilities at its doorstep; the only one capable of exhibiting every one of the most modern wide-screen processes; and the only one engineered to fully utilize the maximum potential of the new accoustical technology. The amici curiae, whose holdings included the oldest houses in the area, quite naturally made every effort to convince the court that the New Haven thentre market did not need an additional facility, and complained bitterly that if construction were permitted they would be driven out of business. The court rejected these arguments to the extent that it granted the petition; yet it severely restricted the competitive ability of the new theatre, rendering it a subsequentrun house. In so doing, the benefits which competition traditionally brings were interdicted, and consumer choice was frustrated at an overall economic cost to society. 203

201. Id. at $345 \mathrm{n} .72$.

202. See note 192 supra.

203. Because the new theatre was judicially restricted in its ability to show first-run product, the consumer had to forego the better parking facilities, the advantages of secing the latest widescreen technology, and the pleasures of the latest stereophonic and acoustical developments offered to him by the new theatre, (see note 165 supro and accompanying text) in order to see the first-run product when he preferred to do so. This represents a cost to consumers and to the economy as a whole. In another context, one authority writing that the economic cost to consumers of permitting cartels to exist an be the same as permitting merchants to collusively agree to close up shop on Sundays, makes this same point in another way:

Consumers who lose the convenience of shopping on Sunday are deprived of something that is as much an economic good as is $\$ 50$. There is no acceptable way for a judge to decide that a restriction [i.e, a cartel] in the offering of a convenience is any less objectionable than a restriction in the number of automobiles sold.

Bork, supra note 165 at 835 . The court's and Justice Department's attempt to stifle competition at the consumer's expense had much in common with amicus Bailey's attempt to prevent the construction of a new theatre in Greater New Haven altogether. Bailey sued in the circuit courts of the State of Connecticut, to prevent the construction of the new theatre. The theory of this suit was that the erection of a theatre in the Hamden Shopping Center would violate the zoning laws of that community, and, therefore, that the public interest demanded that such construction be prevented. He lost. See Whitney Theatre Co. v. Zoning Bd, 150 Conn. 285 (1963). 
The harmful effects on competition which have resulted from many of the acquisition cases are particularly unfortunate in light of the historic purpose of the Paramount decrees. In Paramount, the Department of Justice successfully sued the eight leading motion picture companies of which five, the majors, were vertically integrated with exhibition circuits. One primary purpose of the suit was to eliminate the monopoly in first-run exhibition obtained by these circuits in many towns throughout the country. The economic theory on which this branch of the case proceeded was that

[T] he pooling of the purchasing power of an entire circuit in bidding for films is a misuse of monopoly power insofar as it combines the theatres in closed towns with competitive situations. ${ }^{204}$

The catch-phrase was "transfer of monopoly power." The objective was to break this monopoly power by forcing divestiture of at least one theatre in each "closed" or monopolized town. ${ }^{205}$ The acquisition clause was then written into each decree, requiring judicial approval of the purchase or construction

204. United States v. Paramount Pictures, Inc. 334 U.S. 131, 154-55 (1948).

205. This branch of the Paramount case proceeded on theories of predatory practices, transfer of monopoly power, "deep pocket" bidding and other exclusionary practices conventionally considered monopoly-gaining devices, and as such illegal per se. Stated in its pristine form the theory which governed the exhibition branch of the Paramoum case and justified the forced divestitures of theatres and the acquisitions clauses appears in United States v. Griffith, 334 U.S. 100 (1948):

A man with a monopoly of theatres in any one town commands the entrance for all films into that area. If he uses that strategic position to acquire exclusive privileges in a city where he has competitors, he is employing his monopoly power as a trade weapon .... It may be a feeble... weapon where he has only one closed or monopoly town. But as those towns increase in number throughout a region, his monopoly power in them may be used with crushing effect on competitors in other places. ... Though he makes no threat to withhold the business of his closed ... towns unless the distributors give him the exclusive rights in the towns where he has competitors, the effect is likely to be the same where the two are joined. When the buying power of the entire circuit is used to negotiate films for his competitive as well as his closed towns, he is using monopoly power to expand his empire.

Id. at 107-08. Accord, Schine Chain Theatres, Inc. v. United States, 334 U.S. 110, 116 (1948).

This whole theory of injury to competitors, with its component parts including exclisionary practices and price-cutting, has come under heavy fire as unfounded in economies, and thus, as erroneous in law. See Director and Levi, Law and the Futurc: Trade Regulation, 51 Nw. U.L. Rev. 281 (1956) ; McGee, Predatory Price Cutting: The Standard Oil (N.J.) Case, 1 J. L. \& Econonmcs 137 (1958); Bork \& Bowman, The Crisis in Antitrust, 65 Colum. L. Rev. 363, 366-68, 402 (1965).

This Comment, however, accepts the economic postulates of the Paramount case, as previously developed in Griffith and Schine, as fait accompli. They are the theories governing antitrust law in the motion picture industry, and the decrees rest solidly upon them. Indeed, however dubious the economic and legal basis of Paramount, this topic lies well outside the scope of the present endeavor. For these reasons, all analysis and conclusions which follow proceed from the theory of Paramont and only make sense when viewed from within its confines. 
of any further theatres by the defendant circuit for the specific purpose of assuring that no defendant circuit would ever again "close," or monopolize, a town. As abundantly illustrated by the Representative Cases, this purpose has been lost in the shuffle. Only once in the numerous acquisitions cases did it ever come to the surface. In this case, ${ }^{200}$ Stanley Warner's petition to buy the Lone Star circuit comprising 37 theatres in Texas, the Justice Department attacked the purchase not on the grounds that it would cause an "undue restraint" of competition in any local market, but rather on the ground that a circuit should not be allowed to merge with another circuit because of the dangers of "circuit buying power" and large size. This line of attack forced the court to meet the issue of what the Paramonnt acquisitions clauses were designed to do; and what it said in that case should have provided a guide for the disposition of all previous and subsequent petitions, although, as the record indicates, it has not.

There is no doubt that the Paramonnt Decrec and its satellite consent judgments were intended to stamp out the evil of monopoly and the stifling of competition through the misuse of buying power. . . . But the target was the misuse of circuit buying power, not a naked financial potential. The root of the evil consisted of the closed towns which the operators could use as a bargaining device to obtain favorable treatment in competitive areas. That was the basic reason for the compulsory divestitures which put an end to the closed towns. At the hearing upon the submission of the Paramount Consent Judgment on March 3, 1949, for Court approval, the representative of the [Government] ... Mr. Robert L. Wright, stated that the decree dealt with "the problem of opening up closed towns, rather than in terms of size. The aim here has been to see that this circuit does have opposition at all critical points so that there are alternative outlets in all locations where it operates, and that in our view is a far more effective means of dealing with the problem of circuit buying than to say in some decree, provide a form of dealing and negotiating licenses."200

Against the background of the history of the Paramount case, this statement by the court and the explanation of the decrees offered by the Government's attorney who, in effect, wrote them, provides the key to the errors made in the Representative Cases. What the court has done in Cheltenham, Hamden and Fayetteville, for example, is determine if any competitor is in danger of being eliminated or competitively disadvantaged by an acquisition. If so, the court denies the petition or restricts it. The focus is on the fate of specific competitors, rather than on the general market conditions and the economic status of all competitors - the considerations which would determine the likelihood of a town's being "closed."

The Department of Justice and the amici curiae have, in part, justified their blatant disregard for the overall competitive milieu of the specific market involved and the anticompetitive provisions in the petition orders - the restrictions upon the four circuits' ability to compete freely - by asserting that it is

206. United States v. Warner Bros. Pictures, Inc., 1962 Trade Cas. 77074 (S.D.N.Y. 1962) (hereinafter referred to as the Lone Star Circuit opinion).

207. Id. at 77075-76. 
not competitive inefficiency which would destroy existing competitors, but the scarcity of film product available for exhibition. Thus, in Cheltenham it was agreed that no more than 79 pictures released in 1958 and 81 released in 1959 could be regarded as "quality pictures or pictures with box office significance"; ${ }^{208}$ this was allegedly too little product to keep more than three key run theatres alive in that market. ${ }^{209}$ This shortage provided the basis for the Government's demand for restriction on Stanley Warner's overall competitive potential: "The Government agrees that there is a shortage of quality pictures. ... It is for this very reason that it has asked that certain restrictions be placed on Stanley Warner." ${ }^{\text {210 }}$ The assumption is that the acquisition clause of the Paramount decrees would be violated if Stanley Warner's new and competitively superior facility drove certain competitors out of business, irrespective of whether, even with their demise, the market remained sufficiently competitive. And the correlative assumption must be that the Sherman Act is a directive to the courts to prevent one competitor from extinguishing another.

These assumptions are erroneous, even if there is a shortage of product such that only a certain number of theatres can survive in a given market. Preventing or restricting the construction or operation of new, more attractive and efficient, theatres ${ }^{211}$ in order to preserve existing less desirable facilities represents a misallocation of the economy's resources which should not be encouraged by judicial fiat. ${ }^{212}$ Preserving existing facilities at the expense of newer ones locks investment into theatres which the movie-going public considers relatively less desirable. The net effect is to place artificial obstacles in the way of what would otherwise be the natural movement of capital into an area where it might obtain a high return. Ultimately such restrictions on free competition

208. Post-Hearing Memorandum of the Government in the Cheltenham case, subra note 87, p. 8 .

209. The Department raised the same argument in National General's recent Canoga Park, California, petition, supra note 180. But instead of accepting it, as in Chellcrham, the court rejected it.

In this highly competitive industry, where success and failure frequently turn on the vagaries of public taste, first-run moving pictures often establish their "quality" status only through a 20/20 hindsight appraisal. The evidence adduced at the hearing was not sufficient to permit this Court to draw the inference that first-run product should by definition be so limited [Government argued that "quality" product was "post-television quality" or films with minimum domestic box office gross of $\$ 1$ million] and that consequently it is in such short supply that nono is available for an additional theatre.

Canoga Park opinion, p. 7.

210. Government's Post-Hearing Memorandum in the Cheltenham Case, supra note 87, p. 7.

211. Of course, in the context of the shortage of product argument, only petitions to build new theatres are considered, since they alone add additional screens to their respective competitive situations. Petitions to acquire pre-existing facilities add no addltional film-buyers, and thus could not materially affect the supply of product for existing competitors.

212. See authorities cited in notes 165,192 supra. 
prevent the creation of wealth because they deny consumer want satisfaction.213 Viewing the inability of existing theatres to survive the advent of new competition in terms of shortage of product, moreover, overlooks the probability that the decline in the number of films produced annually since the early 1950's is a function of the marked decline in the number of people willing to go to the movies. ${ }^{214}$ The pronounced shrinkage in the patron market has already forced the closing of numerous theatres throughout the nation. It may be, however, that many local exhibition markets still contain more theatres than are warranted by the number of available patrons. If this is indeed the case, continued contraction should be expected. Many local exhibition markets may be unable to support more than one, or at most two, theatres. The antitrust laws, however, are not violated by a circuit's struggling to be one of the surviving theatre operators, as long as it wages its competition fairly. "In other vords, a natural monopoly market does not of itself impose restrictions on one who actively but fairly, competes for it, any more than it does on one who passively acquires it."215 Rather, the antitrust laws favor wide open competition, because it may make a significant difference which of the many competitors struggling for survival wins:

An interesting speculation might be whether the antitrust laws were intended to protect one natural monopolist against another. ... Since these

213. This argument is, of course, a tautology, wealth being itself conventionally defined as the satisfaction of consumer wants; to create wealth is to maximize consumer satisfaction. See Bork, The Rule of Reason and the Per Se Concept: Price Firing and Market Division, 74 YALE L.J. 775, 829-839 passin (1965). The irony in the court's anticompetitive enforcement of the antitrust laws is that the main tradition of these laws has always been a pro-consumer policy. Ibid.

214. Although there were undoubtedly other factors contributing to the decline in film production, the data would support the view expressed in the text. The full impact of television was felt in the mid-1950's and now keeps millions at home.

\begin{tabular}{|c|c|c|c|c|c|c|c|c|c|c|}
\hline YEARS & 1940 & 1944 & 1948 & 1950 & 1952 & 1954 & 1956 & 1958 & 1980 & 1962 \\
\hline $\begin{array}{l}\text { Films } \\
\text { Released By: } \\
\text { MIajor }\end{array}$ & & & & & & & & & & \\
\hline $\begin{array}{l}\text { Distributors } \\
\text { Mfinor }\end{array}$ & 375 & 272 & 253 & 265 & 275 & 226 & 237 & 236 & 193 & 155 \\
\hline Distributors: & 98 & 137 & 153 & 160 & 78 & 70 & 72 & 95 & 46 & 45 \\
\hline Total: & $\overline{473}$ & $\overline{a n 0}$ & $\overline{406}$ & $\overline{425}$ & 353 & 296 & 309 & 331 & $\overline{239}$ & 200 \\
\hline
\end{tabular}

The 1964 figures are Major Distributors 150; Minor Distributors 54; total: 204 releases. Data from Theatre Owners of America, Inc, 1501 Broadway, New York 36, N.Y. $\begin{array}{lllllllllll}\text { YEARS } & 1940 & 1944 & 1948 & 1950 & 1952 & 1954 & 1956 & 1958 & 1960 & 1962\end{array}$

Weekly Attend-

ance at U.S.

theatres [est.

$\begin{array}{lllllllllll}\text { in millions] : } & 80.0 & 85.0 & 90.0 & 60.0 & 51.4 & 49.2 & 46.5 & 39.6 & 40.4 & 42.5\end{array}$ Data from Firar Daily Yearbook of Motron Pictures 115 (1964).

215. Union Leader Corp. v. Newspapers of New England, Inc, 284 F.2d 582, 584 (1st Cir. 1960). 
laws are concerned primarily with the public interest, ... it may be that they would not be involved if, for instance, the product provided by either party would be the same. However, we cannot say that it would not be in the public interest to have one newspaper [or theatre] rather than another. Where there is no identify of performance we will not say that the public does not have an interest in competition even though that competition be an elimination bout. ${ }^{210}$

In the exhibition market, where the facilities, location, and film-licensing policy of a theatre are significant to the theatre-going public, it certainly does make a difference which of two or more competitors wins the struggle for survival. For these reasons, it is erroneous to say that the antitrust laws compel the court to restrict one competitor as the Government and the amici curiae maintain is proper; rather, regardless of whether product is short or the patron market is shrinking, the public's interest would require that all available product be exhibited by those theatres best able to maximize consumer satisfaction. This point of view seems especially appropriate where, as in all acquisition cases to date, no one has assumed that all competitors will be eliminated and a monopoly will result.

\section{Alternative Approaches to the Acquisitions Clauses:}

\section{A RETURN to CoMpetition}

This comment has considered in great detail a most important and unusual experiment in preventive antitrust. To date this experiment must be considered a disappointment. The Paramount decrees, originally designed to foster and stimulate competition in an industry previously shot through with anticompetitive restraints, have themselves become instruments for the restraint of trade. The court, encouraged, if not led, by the Justice Department has engrafted on the "unduly restrain competition" standard the dominance concept. This concept, by focusing on a petitioner's size and ability to make business less profitable for one or more competitors, rather than on the viability of competition itself, has ineluctably led the court and the Department to the protection of those competitors. The exaggerated and extraordinary role permitted the amici curiae is symptomatic of this preoccupation with competitors. The criteria used to determine dominance, moreover, are founded on fuzzy market definitions and on the utilization of economically and legally unreliable factors, such as seating capacity and number of theatres.

This unhappy performance must force a return to the origins and raison d'etre of the acquisitions clauses. As already developed, the historic purpose of the Paramount decrees was to root out the evil "of the closed towns which the operators could use as a bargaining device to obtain favorable treatment in the competitive areas." 217 This was accomplished by the divestiture clause which made certain that the circuits "have opposition at all critical points so that there are alternative outlets in all locations where [they] operate. . ."1818

216. Id. at 584 n. 4.

217. The Lone Star Circtit opinion, 77075.

218. Ibid. 
In addition, the decree contained distribution clauses which required that product be offered and purchased on a film-by-film, theatre-by-theatre basis, rendering circuit buying and transfer of monopoly power impossible.210 The acquisitions clauses were designed as additional mechanisms for implementing this purpose; the District Court was assigned the responsibility of seeing that the defendant circuits by making acquisitions would not monopolize numerous exhibition markets once again.

Although the acquisitions clauses may have been thought desirable in 1949 when the Paramount decrees were written and their effectiveness was at best speculative, the acknowledged efficacy of the distribution and divestiture clauses and the striking transformation of the exhibition industry during the last 15 years has rendered the acquisitions clauses unnecessary. The District Court itself has emphasized the unprecedented success of the Paramount decrees.

The ills found to have existed in the moving picture industry were eradicated with an effectiveness, precision and finality unique in antitrust litigation. The penalties have been exacted and paid.

There is ... no basis for any apprehension that the condemned practices of mass purchasing are about to be revived. ${ }^{220}$

The competitive changes wrought by the decrees have been matched and hastened by the growth in size and proliferation in number of dynamic local, regional, and national circuits. Today, many of these circuits possess the access to capital, the quality of management, and the efficiencies of scale to enter freely any competitive area in the country. ${ }^{221}$ The distribution clauses, moreover, assure that having entered a specific market, the given circuit must receive treatment equal, in terms of access to product run and clearance, to that received by existing competitors with equivalent facilities. A final goad to competition is the demise of the horizontal cartel among the exhibitor defendants which had existed prior to the Paramount litigation.202 In this posture,

219. See the provisions of the decrees, supra note 171.

220. The Lone Star Circuit opinion, 77076.

221. The local and regional circuits, of course, are somewhat more limited, but they, too, are expanding significantly and should continue to do so. The Wometco Circuit, for example, is the strongest in Greater Mfiami, and thus in South Florida. Its expansion, however, has not been limited to its home territory. Within several months, when its new theatre is completed in Gainesville, Florida, 360 miles north of Afiami, Wometco will be American Broadcasting-Paramount's strongest competitor in that local market. See note 177 supra. Other major national, regional, and local circuits of great competitive significance are listed in note 225 infra.

222. One of the most important by-products of this decartelization of the exhibition market is the movement of each of the four active spin-off circuits into each other's territory. See, e.g., the Loew's Mliami acquisitions, discussed in notes 44-51 supro, and accompanying text. [Loew's moved into an area traditionally the territory of Ameriean Broadcasting-Paramount (Florida State Circuit)]; the Stanley Warner La Mfirada acquisition, discussed in notes 52-63 supra, and accompanying text (Stanley Warner here invaded National General's territory). The National General Canoga Park case gives evidence of another Stanley Warner invasion of National General's territory. Here 
it is highly unlikely that any one circuit could close a substantial exhibition market for any significant period of time. ${ }^{223}$ Even should an occasional geographic market be closed, the injunctions requiring that film product be offered theatre-by-theatre would prevent the transfer of the monopoly power so obtained to competitive situations. But, more important, the Department of Justice and any local theatre owner or distributor injured by the circuit's obtaining a monoply possess sufficient statutory weapons to remedy this unlikely situation - for example, section 2 of the Sherman Act and section 7 of the Clayton Act. In any event, the acquisitions clauses today are a haphazard and discriminatory device for preserving competition in all competitive areas, as their onus falls only on four ${ }^{224}$ of perhaps several dozen circuits with equal potential and incentive to monopolize a local market.25 Given the peculiar

Stanley Warner had already built a new theatre 1.4 miles from National's proposed site, which would give National's new theatre severe competition for every picture to be shown in their local, multiple-run submarket. Note 180 sipra.

223. In this regard, the ubiquitous presence of General Drive-in or Smith Management Corp., the predecessors of General Cinema Corp., in Stanley Warner's Chellenham and La Mirada cases is very significant. General Cinerna now operates 74 drive-ins and shopping center theatres and is building 31 more. See Annual Report for 1964, General Cinema Corp., Feb. 19, 1965. In Cheltenham, (see text at note 78 stipra) and in La Mirado, (see text at note 62 supra). General Cinema was prepared to build on Stanley Warner's proposed sites, if the court refused to grant the Stanley Warner petitions.

224. RKO Theatres, Inc., the fifth spin-off circuit has, at least until this ycar, not been acquiring new theatre properties. See note 7 sipra. Thus there are only four circuits against which the consent decrees continue to run, and to which the acquisition clauses therefore apply: Stanley Warner, approximately 207 theatres; American BroadcastingParamount Theatres, Inc., approximately 413 theatres; Loew's Theatres, Inc, approximately 56 theatres; and National General Corp., approximately 225 theatres. They control, with RKO, roughly 955 of the nation's 13,750 four-wall and drive-in theatres. The data concerning circuit holdings have been obtained from papers submitted by the five spin-off circuits to the Antitrust Division of the Department of Justice on May 24, 1965. The figure on total theatres in operation will appear in the forthcoming Finar DaILY YEAnuoors of Motron Pictures for 1965.

225. In terms of naked financial potential, the leading national circuits, tunaffiliated with the five spin-off circuits, are: General Cinema Corp., 105 theatres (see note 223, supra); and United Artists Theatre Circuit, 271 theatres, Frum Darly YeAruoor of MoTION PICTUREs 1078-80 (1964), which is composed of Rowley United Theatres, 96, United California Theatres, 72, Metropolitan Playhouses, 83, and United Artists Circuit, 20. Id. at $1072,1080,1079$.

The leading regional circuits are Martin Theatres, 140 theatres (southern states); Brandt theatres, 116 (Conn., N.Y.C., N.J. and upstate N.Y.); Commonwealth theatres, 117 (midwest); Prudential New York theatres, 81 (Conn. N.J., N.Y.-Westchester, N.Y.Long Island); Gulf States Theatres, Inc., 65 (gulf states); Frontier Theatres, Inc., 85 (Tex. N.M.); Central States, 68 (Iowa, Neb.); Schine Circuit, 61 (N.Y., Ohio, Ky., Del., Md.) ; Stewart \& Everett, 55 (N. Car., S. Car.). Id. at 1064, 1044, 1047, 1070, 1080, 1057, 1055, 1046, 1073, 1076.

Examples of successful local circuits are: Butterfield Theatres, 63 (Michigan); Pacific Drive-in, 60 theatres (California); Floyd Theatres, 39 (north Fla.); Jefferson Amusement Co., 39 (Texas); Skouras Theatres, 53 (N.Y. and N.J.); Walter-Reade- 
effectiveness of the decrees, ${ }^{226}$ and the highly competitive structure of today's national exhibition industry, it is exceedingly difficult to justify the continued existence of the acquisitions clauses. For this reason, the District Court should exercise its continuing jurisdiction to strike ${ }^{227}$ these clauses from the Paramount decrees. The national exhibition market having been made competitive, the only function of the antitrust laws has been served and the District Court's responsibility has been fulfilled. ${ }^{228}$ There is no reason not to allow this competitive market to regulate itself.

Sterling, 41 (N.Y., N.J.) ; Wometco Theatres, 34 (Fla, Bahamas). Id., at 1045, 1068, 1053, 1060, 1074, 1081, 1083.

A score of other regional and national circuits could be listed. These circuits all possess the same incentive to attempt to "close" or monopolize the local exhibition market as do the big four spin-off circuits: the permanent elimination of competitive bidding; stronger negotiating positions for sharing advertising expenses with distributors, obtaining adjustments of rentals when bids turn out to be excessive, and getting better play dates; and the prevention of disadvantageous day-and-dating of conventional and drive-in-houses. Many of these circuits have been successful in monopolizing various local exhibition markets - or, at least, so successful that they have been vulnerable to suit on grounds of monopolization. Two examples, are the Attomey General of Hiswail's suit against Royal Theatres, Itd, and Consolidated Amusement, two companies controlled by William Foreman, who controls Pacific Drive-in, and the Attomey General of Washington's suit against Sterling theatres and "an army of affiliates" (Sterling itself controls 32 theatres, mostly in Washington) id. at 1076. The former ended in a consent decree wherein Foreman gave up his $51 \%$ control of Royal, and the latter is still in litigation, although the Washington Attorney General has lost the first round. See id. at 81 .

226. See text, supra note 220. Even Conant mixes criticism of the decrees with the grudging concession that they radically changed the industry's structure, practices and conditions. CoNart, 208-10, 218-19. However, this concession is limited by Conant's fears of the "circuit buying power" and "monopoly power" of the spin-off circuits; ibid. Yet, his book can be read carefully from cover to cover without the resder's ever discovering a definition for this mysterious "power," or even so much as an illustration. Nor does Conant offer any theory of how this "power" operates in the market place. In view of the provisions of the decrees requiring theatre-by-theatre licensing of all films, this fear is irrational. It is something else again to argue that the decrees are not being enforced; if so, then the Department of Justice or the Federal Trade Commission have been derelict in their duties. Continued enforcement of the acquisitions clauses is not likely to solve this kind of a problem.

227. The court could act on the motion of one of the parties in an acquisition proceeding, or it could act sua sponte within the broad scope of its equity powers.

228. It is, of course, only a "shorthand" way of spealing to say that the purpose of the antitrust laws is to preserve or promote competition. Taken literally, it is inaccurate. The goal is maximization of consumer want satisfaction, see Bork, supra note 213 at 829, 830, 831-39, passinz, for which a competitive market place in all goods and services is essential. But certainly, if there is some dispute over the ultimate goal of antitrust law, i.e., whether it may be stated at all in economic terms, see, e.g., Blake and Jones, supra note 165, there can be no argument about the purpose of the acquisitions clauses or the court's role under them; it is economic: to preserve competition (the word itself is used, see text accompanying note 10 supra) in all exhibition markets in order to prevent transfer of monopoly power. 
One major obstacle to striking the acquisition clauses may be the well established judicial aversion to modifying consent decrees absent the most compelling circumstances. The most forceful statement of this attitude was made by the Supreme Court in United States v. Swift \& Co.228

We are asking ourselves whether anything has happened that will justify us now in changing a decree ... the inquiry for us is whether the changes are so important that dangers, once substantial, have become attenuated to a shadow. No doubt the defendants will be better off if the injunction is relaxed, but they are not suffering hardship so extreme and tunexpected as to justify us in saying that they are the victims of oppression. Nothing less than a clear showing of grievous wrong evoked by new and unforeseen conditions should lead us to change what was decreed after years of litigation with the consent of all concerned. ${ }^{230}$

An additional consideration militating against elimination of the acquisitions clauses might lie in the maxim that an "ounce of prevention is worth a pound of cure." Thus, the Justice Department might argue that it would be impossible to continually investigate the exhibition industry in order to detect and eradicate local or regional exhibition monopolies created by the spin-off circtits through construction or purchase of existing theatres. Despite the remoteness of this possibility, ${ }^{231}$ the spectre it creates may very well persuade the District Court to retain the acquisitions clauses in the decrees.

If the acquisitions clauses are retained, they should be reinterpreted to render them consistent with the purposes of the Paramount decrees and to eliminate their current anticompetitive application. Such a re-interpretation must begin with the fundamental reason why the defendant circuits were forced to divest theatres in their "closed towns" and were enjoined from acquiring additional facilities in any market without judicial approval: to insure that the circuits "have opposition at all critical points so that there are alternative outlets in all locations where [they] operate ...."232 It follows from this objective that the "unduly restrain competition" standard requires the court, in passing on the purchase or construction of a new theatre, to determine whether that theatre will face at least one competitor capable of depriving it of top quality product in a bidding situation, whether or not bidding is in fact the mode of distribution in that market.

This suggested test involves several considerations. Because profitability in the patron market is so largely dependent upon success in purchasing product to exhibit, the court would first have to determine whether, in the subjective judgment of a hypothetical film distributor, an outlet alternative to the acquired theatre in fact exists. Since distributors allocate product according to their sub-

229. 286 U.S. 106 (1932).

230. Id. at 119 .

231. It presumes that the spin-off circuits, the notorious culprits of the industry, having been once badly burned, will again go near the fire.

232. Quotation from argument of Mr. Robert L. Wright, chief Government counsel who authored the Paramount decrees, before the 3-judge court in 1949, cited by the court in its Lone Star Circuit opinion, discussed in text accompanying note 207 supra. 
jective evaluation of the bounds of the geographic market, and since the suggested test looks to whether the acquired theatre will lose product to an existing competitor in the same geographic market, the court should accept, without further inquiry, the market as defined by a majority of the major distributors. This will eliminate the uncertainty inherent in present arbitrary market definitions. For the same reasons, the court should look to the competitive qualities to which a distributor looks in evaluating a bid. It is only in this respect that seating capacity should be considered relevant as one of several factors including location of theatre, modernity of equipment, parking facilities, overall condition of the theatre and its appointments, and general policy of the management as to length of run, road shows, and willingness to compete for expensive product.

In those cases where the court is uncertain of the existence of a competitor whose presence will keep the petitioning circuit from monopolizing the market, the inquiry must go on. As the present wave of theatre building demonstrates, the local exhibition markets are not static. It is therefore incumbent upon the court, in judging the existence of competitive alternatives in cases involving new acquisitions, to assess the possibility that present competitors will modernize, build new facilities, or change their management policies to meet the new competition. Moreover, as the acquisitions cases themselves indicate, new entry into local markets is easily accomplished.233 For these reasons, the court should look to the identity of the pre-existing theatre operators. If a strong local, regional or national circuit is presently operating a theatre which will be rendered competitively inferior by a petitioner's acquisition, it is likely that this competitor would modernize its existing theatre, or if this were impractical, would build a new one to preserve or recapture its market share. Excellent illustration is provided by Stanley Warner's Cheltenham acquisition, which was motivated by the competitive inferiority of its Yorktown Theatre relative

233. In terms of the economics of entry, any given local motion picture exhibition market illustrates the archtype of easy entry, especially for firms established in olther local markets - whether geographically contiguous or remote. Bain gives three conditions for easy entry, all of which are met in motion picture exhibition:

(1) Established firms have no absolute cost advantages over potential entrant firms;

(2) Established firms have no product differentiation advantages over potential entrant firms;

(3) Economies of large-scale firms are negligible.

BAIN, Barriers to New Courpetition 12 (1956). Only (3) may appear dubious; but all experienced operators in the industry will testify to the disadvantages facing the large circtuits due to the costs of supporting large management and bookkeeping staffs. Under the theatre-by-theatre clause of the decrees, any operator, no matter how small, may obtain product if he is willing to pay for it; often the smaller theatre operator with lower overhead can afford to pay the distributors more. If it be asserted that the circuits have "deep pockets" and will bid from a long pocketbook, this is something else again, and such an assumption brings the argument away from the economies of entry to the area of predatory practices - a distinctly different problem, and itself an area of much dispute. See note 205 supra. 
to the Ellis Circuit's Erlen Theatre. ${ }^{234}$ Similarly, the court should be influenced by the potential entry of other chains operating in nearby local marlets. In fact, both types of situations - the re-entry of an existing competing circuit and the new entry of a circuit competing nearby - are very likely to occur, because both types of circuits already possess experienced local management and local connections with the distribution exchanges located in the territory.

Since the test offered above depends upon the competitiveness of the market as a whole - whether or not the theatre to be purchased or constructed would lose product in a bidding or negotiating situation to any of its competitors it is relevant to consider the competitive milieu of the market. This miliet may be characterized by either predatory practices or the splitting of product among competing theatre owners. While both these practices may be labeled "anti-competitive" in the language of the court and the parties, they have very different implications for the test proposed above.

Evidence regarding past and present predatory practices, such as agreements between the petitioning circuit and the distributors concerning discriminatory runs and clearances, may indicate a likelihood of the continuance of such "predation"235 after the acquisition with the purpose and effect of monopolizing the market. Here the competing theatre owners should be encouraged to inform the Department of Justice of the existence of such anti-competitive or predatory practices. Only the Department, as representative of the public interest, should be permitted to introduce this evidence in an acquisition proceeding. Presumably the Antitrust Division will have made an independent judgment as to the probative value of this evidence before introducing it. And the court should consider this evidence relevant only if convinced that it has a direct bearing on the probable viability of competition after the acquisition. This procedure differs from present practice because it would bar the amici curiae from introducing any evidence concerning anticompetitive practices. This limitation on the amici would have the salutary effect of expediting the proceedings, of removing arguments irrelevant in the context of the particular case, and of eliminating a source of concern for the protection of individual competitors.

Although splitting of product ${ }^{238}$ has never been determinative in the denial of a petition, the Poughkeepsie and Fayetteville cases are representative of several others where the court considered splits as a factor in its decision. The existence of a split, however, should be considered relevant only in an extremely limited sense.

A split has been defined by the Court of Appeals for the Third Circuit in Viking Theatre Corp. v. Paramount Film Distrib. Corp.,"237 as "in essence an

234. See text supra at note 72 .

235. The entire theory of "predation" is itself open to serious question. See note 205 supra. Nevertheless, it is an integral part of the mythology of motion picture antitrust law, and is accepted here for purposes of discussion.

236. See earlier discussion and examples supra in notes 70,92, and accompanying text. 237. 320 F.2d 285 (3d Cir. 1953) aff'd by an equally divided court, 378 U.S. 123 (1964). 
agreement between exhibitors to divide product and to refrain from bidding against each other for pictures on their respective sides of a prepared list." In practice this amounts to taking a group of pictures on the release schedules of one or more distributors and dividing the pictures, assuming two theatre circuits, into two equal lists. The one who did not arrange the lists has the right to the first choice of lists. The next group of films will be split into two lists by the other party, and again the one who did not do the arranging will have the first choice. Another common type of split operates along distributor lines, each participating theatre being assigned the product of one or more distributors which it plays exclusively. The analysis which follows assumes the existence of one of these two basic kinds of splits, but does not in any way proceed from premises or conclusions concerning the legality of this form of market division under the antitrust laws. ${ }^{239}$ Whether such elimination of competition between competing theatre operators is considered illegal per se or defensible under the rule of reason, is irrelevant for the purposes of correctly applying the acquisitions clauses of the Paramount decrees. The presence of a splitting device is relevant only to the extent that it reflects the underlying economic structure of the local market.

A split may either be imposed by the competing theatre owners upon the distributors, who generally acquiesce, or by the distributors themselves. Although a number of reasons have been put forth to explain this phenomenon, in general, an exhibitor-imposed market division proceeds from the desire to eliminate competitive bidding. The elimination of competitive bidding from a market of relatively equal competitors usually results in each competitor obtaining the same quality product he would have received through bidding, but at a considerably lower cost. It has always been unclear why distributors acquiesce in division of their product, but whatever the explanation, it is unimportant. What is significant for the purpose of applying the suggested test to any proposed acquisition is that the split originated with the exhibitors and continues to exist. For such a split proves that the local market has a competitive structure; absent the split, competition would exist in that market. If one theatre were competitively superior to another, it would presumably refuse to eschew competition and divide the market, as the Ellis Circuit's Erlen refused to split with Stanley Warner's inferior Yorktown.240 If in the rare case the split is distributor imposed and higher returns are deliberately foregone, explanation is more difficult. Three reasons have most often been adduced. A distributor may impose a split in order to avoid litigation over his reception of bids and award of licenses. Or he may divide his product so as to insure a full "play-off" of all of it, especially his low quality films probably unable to receive

238. $320 \mathrm{~F} .2 \mathrm{~d}$ at $292 \mathrm{n} .7$.

239. See note 135 supra for general discussion of the factors affecting the legality of a given split.

240. See text supra at note 72. 
an exhibition in a competitive market. ${ }^{241}$ The third reason proffered is the distributor's desire to keep as many outlets as possible alive to avoid monopsony in the product market. As is immediately apparent, the first two reasons would testify to a healthy competitive situation in the absence of a split. If there is constant controversy in a bidding situation, it must indicate that the competing theatre owners think that their bids are comparable and that they are equally deserving of the distributor's product. In those cases where a distributor imposes a split in order to assure a full play-off, competition must exist among the exhibitors, otherwise the low quality films could be placed in those first-run houses unable to compete for better quality product. The third reason alone - the fear of monopsony - would indicate visible imperfection in the competitive structure. But even this would be of dubious validity in assessing competitive conditions for purposes of realizing the goals of the Paramount decrees; for the imperfections may not be so significant that the newly constructed or purchased theatre would not face at least one competitor capable of depriving it of quality product. Since most of the explanations of splitting indicate a viable competitive structure in the area absent the split, and since it is difficult to determine whether a split is distributor or exhibitor imposed, and if distributor imposed, the reasons, the presumption should be that the existence of a split indicates a highly competitive market structure with the Government ${ }^{242}$ bearing the burden of establishing the contrary. Regardless of whether the Government carries its burden, the existence of a split should be considered only one of several factors in the court's ultimate decision; the court should also look to the possibility of entry or re-entry in determining whether the new theatre is likely to face competition in the local market.

The factual determinations necessary to make a finding that the theatre to be purchased or built will face at least one competitor capable of depriving it of top quality product in a bidding situation are not nearly as difficult as they may appear. ${ }^{243}$ First, the court must define the relevant geographic market as

241. So motivated, a split is very similar to a non-contractual form of block-booking or vertical integration, and accomplishes the same purpose for all partics concerned.

242. It is always open for the amici to furnish the Government with evidence to prove the origin and effects of any given split.

243. For example, in the La Mirada case, the existence of the new Vinnicof theatre, and the new Stein and ElectroVision theatres, see text at note 60 supra, going up near La Mirada, should have ended the inquiry. Similarly, once the strong competitive challenge of amicus Ellis' Erlen Theatre was established, see text, silpra at notes 71-75, the Cheltenhan case should have been closed. Likewise in Garden Grove, Wilkes-Barre and Fayetteville $I$, where strong competitors were all very much in being. In the more difficult cases such as Handen, where the new theatre would be superior to all the rest, the court should have looked to new entry and to the probable re-entry of established firms. Moreover, the smaller, less modern Whalley was still a formidable competitor because of its low overhead and ability to offer bids as or more attractive than Stanley Warner's new theatre, see note 233 sipra.

The burden of proof is on the petitioner due to the wording of the decrees, see text supra note 10 . But, in all fairness, it should only be a burden of persuasion; the burden of coming forward with evidence to prove an acquisition zuill "unduly restrain trade" 
delineated by the distributors in terms of competitive zoning. In most cases this delineation will be readily apparent from the run and clearance pattern in the area; if question arises, testimony can be taken in depositions or affidavits from the distributors. Second, the court must look to the competitive qualities of the theatres which will compete with the acquisition as the distributor would look at them in awarding licenses. Expert testimony as to the relative qualities of the various theatres can easily be supplied by the parties. Moreover, evidence as to the paid admissions of each theatre during a given period can easily be obtained by subpoena, ${ }^{244}$ in order to show the performance of all competitors vis-a-vis each other prior to the acquisition. In this manner, a hierarchy of competitors in the area can be assembled, and the leading competitor(s) determined. Third, so far as new entry or re-entry is concerned, the requisite finding can be simplified merely by greater emphasis on the corporate identity of the circuit, local, regional or national, to which the local competitors belong. If they are dynamic and well-financed, competitive alternatives to the acquisition are made likely, if not immediately, at least ultimately. Fourth, since the Justice Department is responsible for initial determination of the probative value of the evidence submitted by amici as to predatory practices and their continuance, the court's difficulties in this area should be reduced. Although difficulties of proof may still inhere in the suggested test, this of course does not warrant its rejection if it is more justified in law and economics than that presently in use. ${ }^{245}$

The motion picture industry has been peculiarly wracked by antitrust litigation. The response of the courts to these suits has produced far-reaching changes in the industry's organization and practices. Throughout the onslaught of complaints, trials, decrees and petitions under those decrees, the overriding objective of the federal judiciary has been the restoration and preservation of competition on all levels of the industry. The administration of the acquisitions clauses, however, has unwittingly worked at cross-purposes with this goal.

should be on the Government. The Justice Department should be required to prove that no nearby competitor is capable of depriving a petitioner of product, or that petitioner has violated the antitrust laws in that local market. The petitioner should not be required to prove the negative $a b$ initio. The costs of subpoena, discovery, and other investigation needed to support this Comment's suggested test should thus fall, to a large degree, upon the Government.

244. Such evidence was easily obtained in the Cheltenham case, see note 174 supro. There is no reason why it cannot be similarly obtained in other cases. Whether or not it is reliable is something else again. Exhibitors are notoriously inaccurate on these figures, although the larger chains are generally reliable. In any case, sworn affidavits, with concommitant threat of perjury indictment for wilful fraud, should be required.

245. Having criticized the court and the Department of Justice for the content they have poured into the acquisitions clauses of the respective Paramount decrees, and having advanced a new approach to these clauses, application of this approzch to specific factual situations would undoubtedly be desirable. But since the court and the parties have proceeded upon a theory different from that suggested by this Comment, the requisite evidence for such an exercise is very largely missing from the available source materials. 
The objective of this Comment in recounting the court's and the Department of Justice's disappointing performance in enforcing these clauses has not been to justify a counsel of despair. Rather, this Comment has attempted to reassess the standards by which the clauses are to be administered, so as to conform them to the philosophy of the Paramount litigation and of the antitrust laws in general - the maintenance of an economy which functions and regulates itself through competition in the marketplace. 